\title{
PERAN TEKNOLOGI INFORMASI DAN KOMUNIKASI (TIK) SEBAGAI ENABLER KNOWLEDGE MANAGEMENT DALAM MEMBAWA INOVASI PADA INDUSTRI KREATIF DI BATAM
}

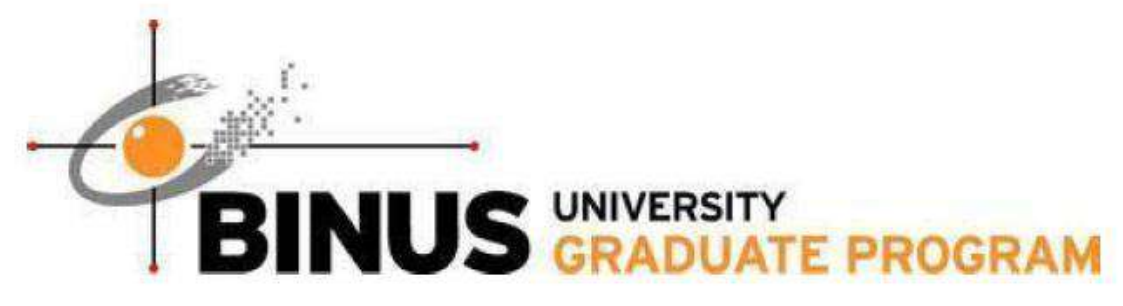

\author{
RESEARCH \\ COSMAS EKO SUHARYANTO \\ (1322202122)
}

Program Pascasarjana Ilmu Komputer

PROGRAM STUDI SISTEM INFORMASI JENJANG S2

UNIVERSITAS BINA NUSANTARA

JAKARTA

2015 
PERAN TEKNOLOGI INFORMASI DAN KOMUNIKASI (TIK) SEBAGAI ENABLER KNOWLEDGE MANAGEMENT DALAM MEMBAWA INOVASI PADA INDUSTRI KREATIF DI BATAM



\author{
RESEARCH \\ COSMAS EKO SUHARYANTO \\ (1322202122)
}

Tesis sebagai Salah Satu Syarat untuk

Memperoleh Gelar Magister

Pada

PROGRAM PASCASARJANA MANAJEMEN SISTEM INFORMASI JENJANG S2

UNIVERSITAS BINA NUSANTARA 


\title{
PERAN TEKNOLOGI INFORMASI DAN KOMUNIKASI (TIK) SEBAGAI ENABLER KNOWLEDGE MANAGEMENT DALAM MEMBAWA INOVASI PADA INDUSTRI KREATIF DI BATAM
}

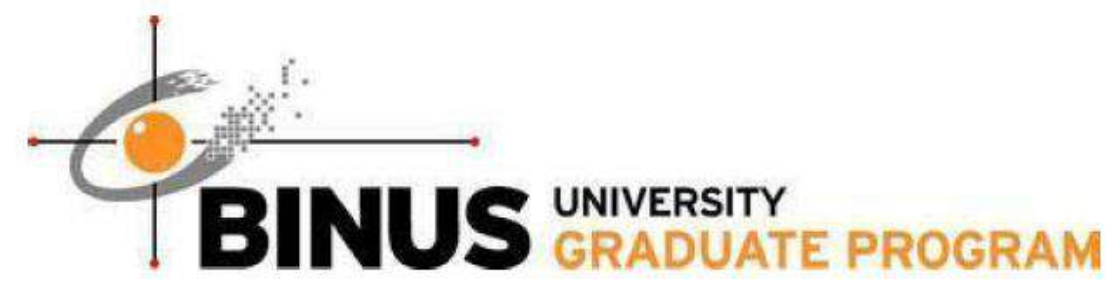

\author{
RESEARCH \\ COSMAS EKO SUHARYANTO \\ (1322202122)
}

Pembimbing:

Dr. Eng. Fergyanto E Gunawan, S.T, M.T

Tanggal : 


\section{MOTTO:}

\section{Per Mariam ad Jesum}

"Totus tuus ego sum, et omnia mea tua sunt" 


\section{HALAMAN PERNYATAAN STUDENTS STATEMENT}

Saya, Nama: Cosmas Eko Suharyanto, NIM: 1322202122 menyatakan dengan sebenarbenarnya bahwa tesis saya berjudul "Peran Teknologi Informasi dan Komunikasi (TIK) sebagai Enabler Knowledge Management dalam Membawa Inovasi pada Industri Kreatif di Batam" adalah merupakan gagasan dan hasil research saya sendiri dengan bimbingan Dosen Pembimbing.

Saya juga menyatakan dengan sebenarnya bahwa isi tesis ini tidak merupakan jiplakan dan bukan pula dari karya orang lain, kecuali kutipan dari literatur dan atau hasil wawancara tertulis yang saya acu dan telah saya sebutkan di Daftar Acuan dan Daftar Pustaka.

Demikian pernyataan ini saya buat dengan sebenarnya dan saya bersedia menerima sanksi apabila ternyata pernyataan saya ini tidak benar.

I, Name: Cosmas Eko Suharyanto, Student ID: 1322202122, truly acknowledge that my thesis with title "The Role of Information Technology \& Communication (ICT) as Anabler of Knowledge Management to Bring Innovation to Creative Industry in Batam” is my concept and project result with guidance from supervisor.

I, also truly acknowledge that content of this thesis are not copyed and not from another people work, except my citation from literature or written interview result and already write in reference list and bibliography list.

That's my acknowledge were truly made and if in reality this acknowledge weren't true, I willing sanction.

Jakarta, 21 Maret 2015

\section{Cosmas Eko Suharyanto}

1322202122 


\section{KATA PENGANTAR}

Puji syukur kepada Allah Bapa, Putera dan Roh Kudus, dan doa-doa Bunda Maria, sehingga penulis dapat menyelesaikan tesis ini. Dalam penyusunan tesis ini, penulis memperoleh banyak bimbingan, bantuan serta dukungan dari berbagai pihak. Oleh karena itu, pada kesempatan ini penulis ingin mengucapkan terima kasih kepada semua pihak diantaranya :

1. Prof. Dr. Ir. Harjanto Prabowo, MM., selaku rektor Universitas Bina Nusantara.

2. Bapak Dr. Ir. Harisno, MM., selaku Kepala Program Studi Manajemen Sistem Informasi Jenjang S2, Universitas Bina Nusantara.

3. Bapak Dr. Eng. Fergyanto E Gunawan, S.T, M.T., selaku dosen pembimbing tesis yang telah memberikan bimbingan dan saran-saran selama penyusunan tesis ini.

4. Seluruh dosen pascasarjana Universitas Bina Nusantara yang telah memberikan kuliah selama penulis menjadi mahasiswa.

5. Bapak Amsakar Achmad, S.Sos, M.SI selaku Kepala Dinas Perindustrian, Perdagangan dan ESDM Kota Batam yang telah memberikan kesempatan pada penulis untuk memberikan informasi yang penulis butuhkan seputar Industri Kreatif di Batam.

6. Bapak Zulkifli, AMP, SE, atas nama Kepala Badan Komunikasi dan Informatika Kota Batam

7. Keluarga yang telah memberikan dorongan dan semangat dalam penulisan proposal tesis ini; isteri saya Santy Evelina Siahaan, putera saya Thomas Aquinas Gregie Benedetto

8. Teman-teman MMSI yang telah memberikan dukungan, saran-saran, serta semangat dalam penulisan tesis ini. 
9. Para Direktur, Pimpinan, Manajer industri kreatif di kota Batam yang telah banyak menolong saya dalam penyebaran kuesioner lapangan.

10. Bapak Supriyanto, ST.,MT., Ketua Ikatan Arsitektur Indonesia (IAI) Kepulauan Riau yang telah dengan kemurahan hati meng-handel kuesioner untuk industri arsitektur di kota Batam.

Akhir kata penulis berharap agar hasil penelitian ini nantinya dapat memberikan manfaat bagi perkembangan industri kreatif di Batam, tempat penulis mengadakan penelitian serta rekanrekan yang membacanya.

Batam, 20 Maret 2015

Penulis 


\begin{abstract}
Creative industries have become a hot issue in the last decade. Along with the growth of information technology, creative industries are increasingly showing their existence, both in terms of quantity and quality in the various forms of innovation. No industry or companies can stay on top without innovation; however, technology alone is not enough to help companies to innovate. It takes a good knowledge management such that the ideas that are stored in the form of tacit and explicit knowledge can be transformed into a new form of product / program / service. Technology will act as a catalyst that enables and facilitates the implementation of the development, transfer, and utilization of knowledge, which will contribute to the improvement and innovation. The objectives of this study are to find the role of information communication and technology (ICT competency) to knowledge management and knowledge management's role to innovation, and to study the indirect effect of ICT competency to innovation in the creative industries. Researchers took five sectors of the creative industries in Batam, namely television, radio, publishing, IT software \& computer services and architecture, with a sample of 150 respondens. To see what factors are dominant in this analysis, researchers using Structural Equation Modeling (SEM ) as a method to perform data processing and analysis. This study found that a significant effect of ICT competency to knowledge management, as well as a positive influence on innovation from knowledge management. The indirect effects show the positive effect of ICT competency to innovation, so that it can be concluded that the ICT competency has become an enabler of knowledge management that ultimately lead to innovation in the creative industries (CES).
\end{abstract}

Keywords: creative industries, information communication and technology, knowledge management, innovation 


\begin{abstract}
ABSTRAK
Industri kreatif telah menjadi isu yang hangat dalam dekade terakhir. Seiring dengan pertumbuhan teknologi informasi, industri kreatif semakin menunjukkan eksistensinya, baik dari segi kuantitas maupun kualitas dalam berbagai bentuk inovasi. Tidak ada industri atau perusahaan yang tetap berada di puncak tanpa melakukan inovasi, namun teknologi saja tidak cukup untuk membantu perusahaan dalam berinovasi. Dibutuhkan manajemen pengetahuan yang baik agar ide-ide yang tersimpan dalam bentuk pengetahuan tacit maupun explicit mendapatkan tempat yang tertuang dalam bentuk produk/program/layanan yang baru. Teknologi akan berperan sebagai katalis yang memungkinkan dan menfasilitasi terselenggaranya pengembangan, transfer dan pemanfaatan knowledge, yang akan berkontribusi kepada improvement dan inovasi.Tujuan dari penelitian ini adalah untuk melihat peran kompentensi teknologi informasi dan komunikasi terhadap manajemen pengetahuan dan peran manajemen pengetahuan terhadap inovasi sehingga dapat dilihat juga peran tidak langsung kompetensi teknologi informasi dan komunikasi terhadap inovasi pada industri kreatif. Peneliti mengambil lima sektor industri kreatif di kota Batam yaitu industri televise, radio, publishing, IT software \& computer services dan arsitektur dengan sampel sebanyak 150 responden.Untuk melihat faktor-faktor apa saja yang dominan dalam analisis ini, peneliti menggunakan Structural Equation Modeling (SEM) sebagai metode untuk melakukan pengolahan dan analisis data. Penelitian ini menemukan bahwa terdapat pengaruh yang signifikan antara kompetensi teknologi informasi dan komunikasi terhadap manajemen pengetahuan, demikian juga pengaruh positif manajemen pengetahuan terhadap inovasi. Dari pengaruh tidak langgung kompetensi teknologi informasi dan komunikasi terhadap inovasi, ditemukan fakta bahwa ada pengaruh positif sehingga dapat disimpulkan bahwa kompetensi teknologi informasi dan komunikasi telah menjadi enabler bagi manajemen pengetahuan yang pada akhirnya membawa inovasi pada industri kreatif (CES).
\end{abstract}

Kata Kunci: industri kreatif, teknologi informasi dan komunikasi, manajemen pengetahuan, inovasi 


\section{DAFTAR ISI}

Halaman Persetujuan Tesis....................................................................................ii

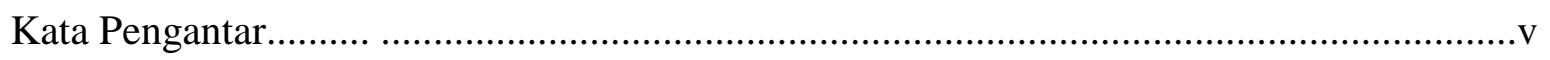

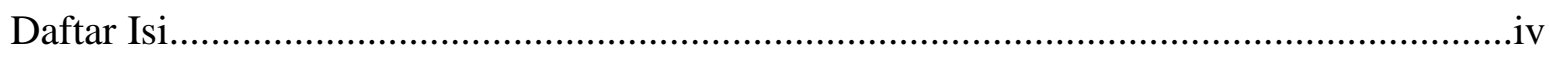

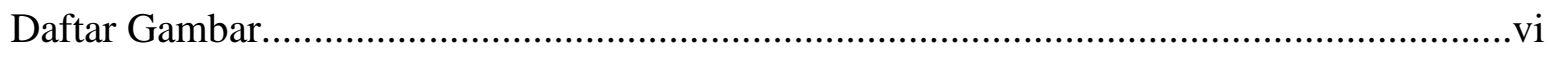

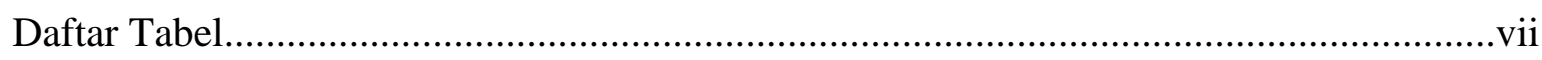

BAB I PENDAHULUAN ....................................................................................................1 1

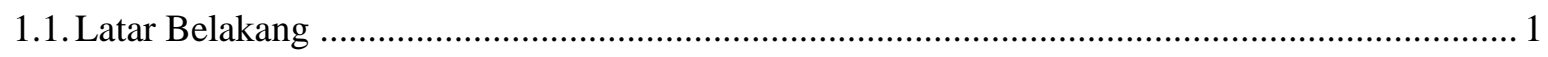



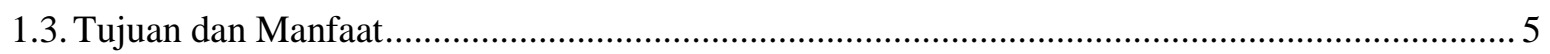

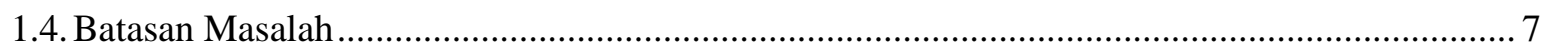

BAB II LANDASAN TEORI...........................................................................8

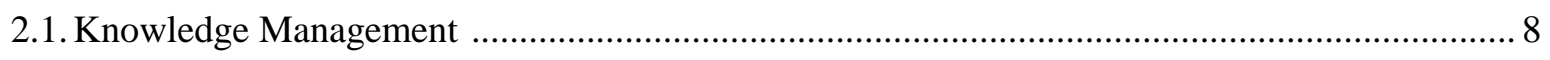

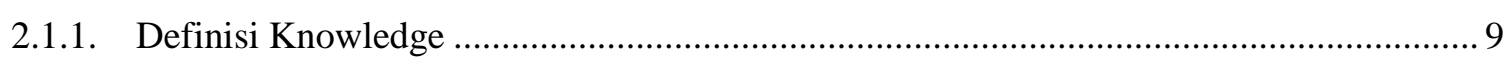

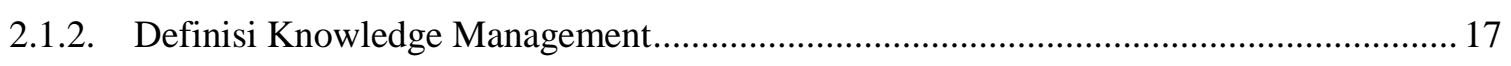

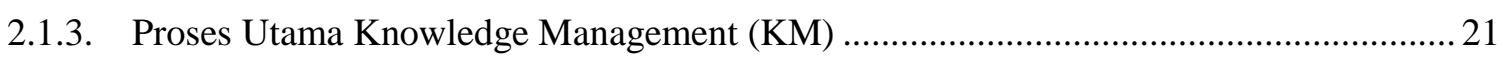

2.1.4. Praktek Knowledge Management (KM Practices) .......................................................... 25



2.2. Teknologi Informasi dan Komunikasi/TIK (Information Communication \& Technology/ICT). 28







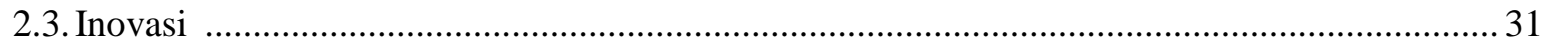



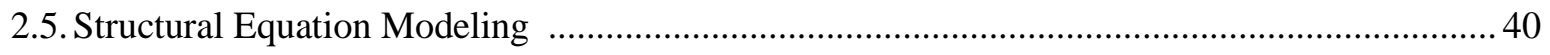

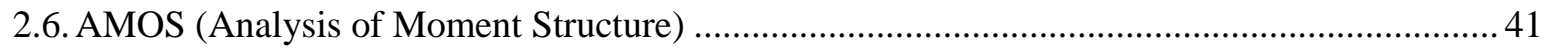

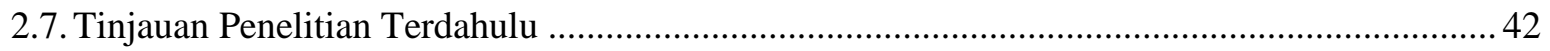

BAB III METODOLOGI PENELITIAN ............................................................43

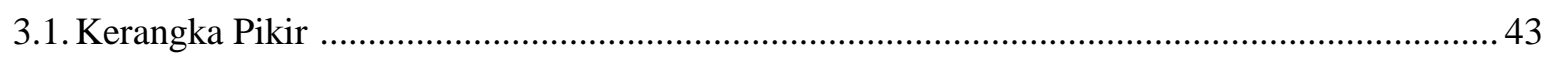




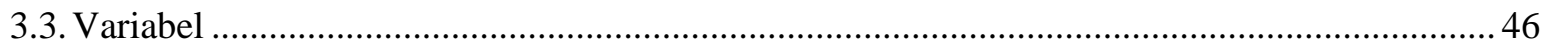

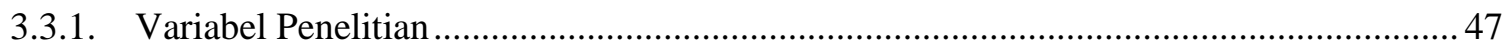

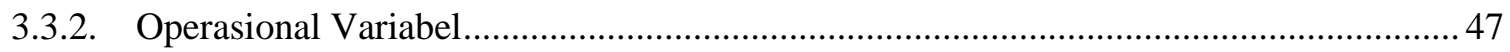

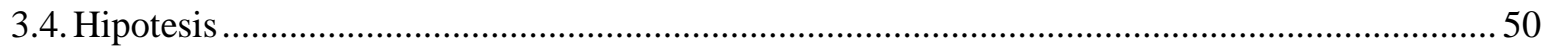

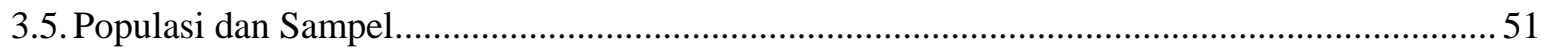

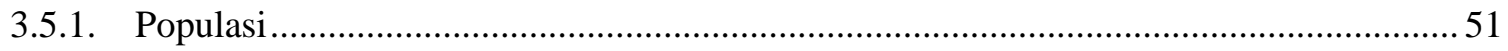

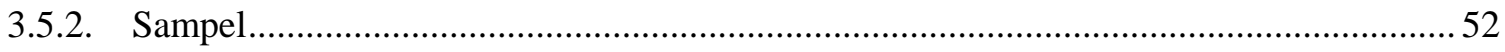

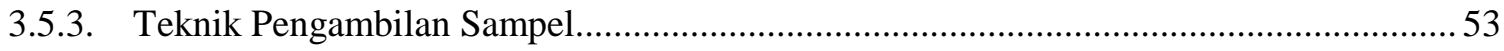

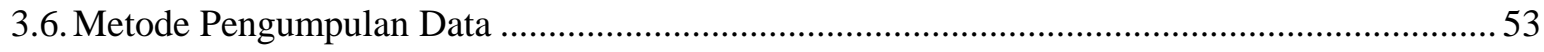

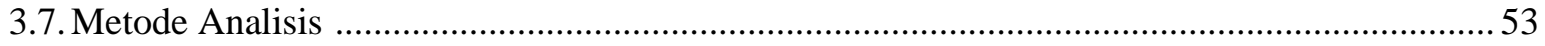

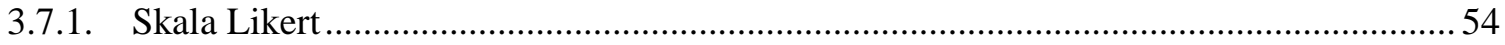

3.7.2. Analisis Faktor Konfirmatori (Confirmatory Factor Analysis/CFA) ............................... 54

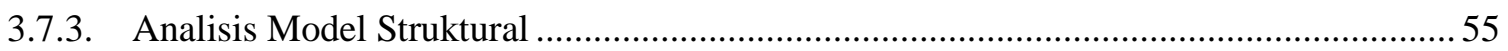

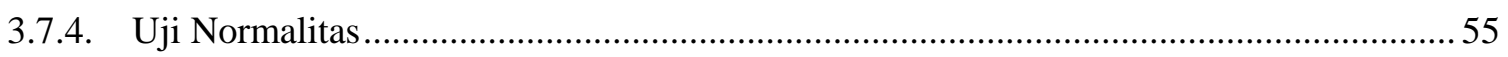

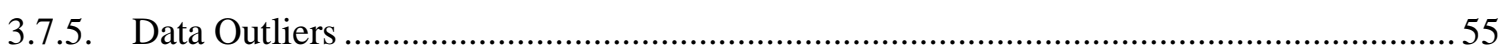

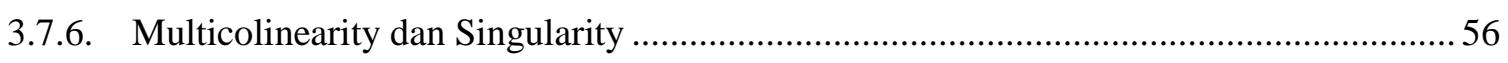

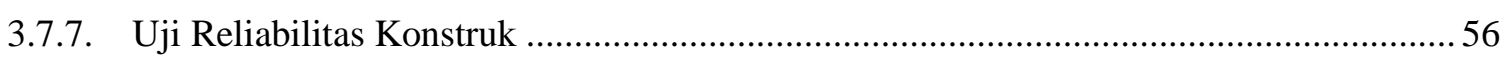

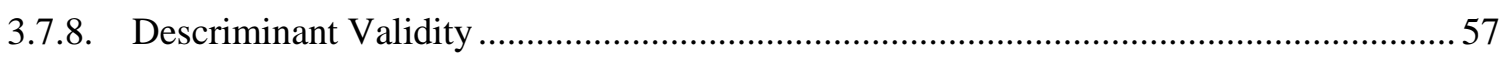

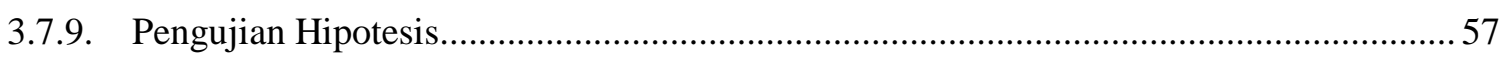

BAB IV HASIL DAN PEMBAHASAN ..............................................................58

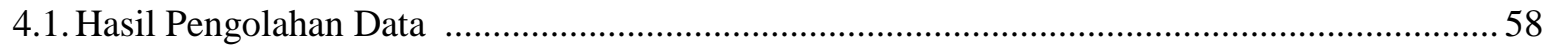

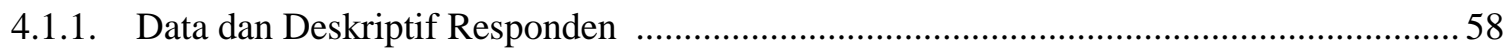

4.1.1.1. Profil Responden Berdasarkan Sektor Kategori Industri Kreatif ................................. 60

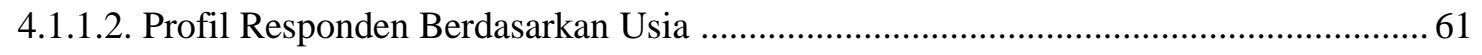



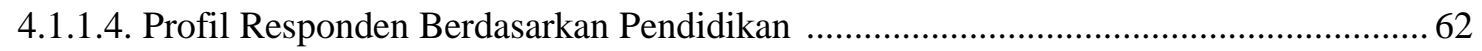

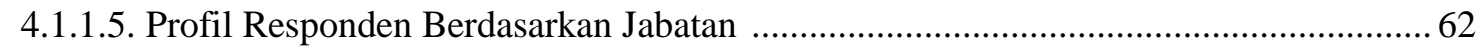

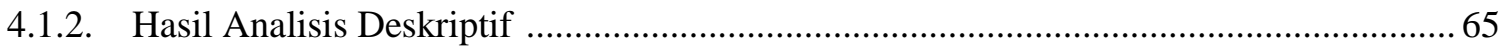

4.1.2.1. Deskriptif Variabel Kompetensi Teknologi Informasi dan Komunikasi ..................... 65

4.1.2.2. Deskriptif Variabel Manajemen Pengetahuan (Knowledge Management) ................... 67

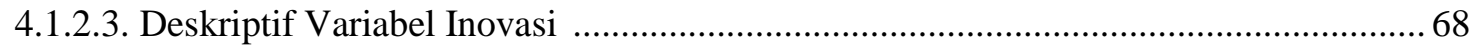

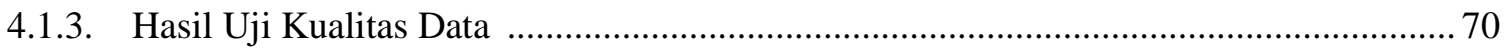

4.1.3.1. Analisis Faktor Konfirmatori (Confirmatory Factor Analysis) Variabel Eksogen ....... 70

4.1.3.2. Analsisi Faktor Konfirmatori (Confirmatory Factor Analysis) Variabel Endogen ....... 76 


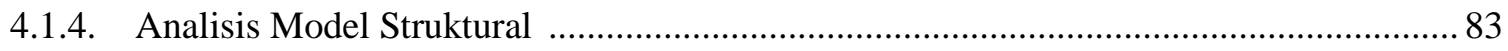

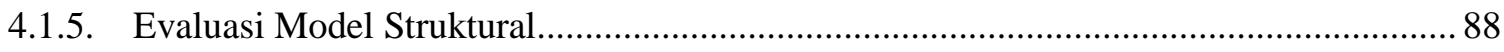

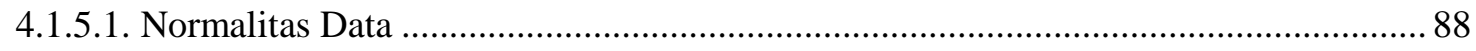

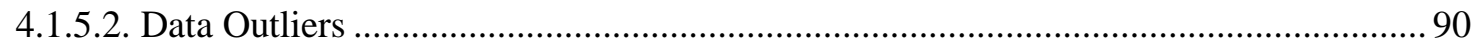

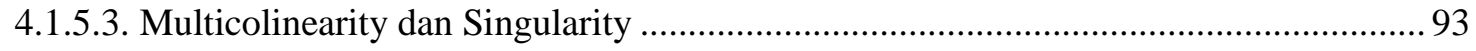

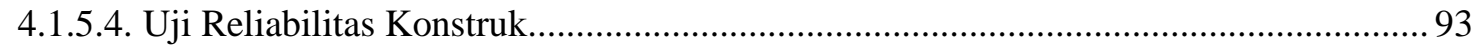

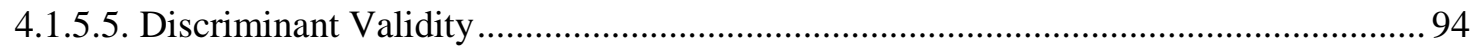

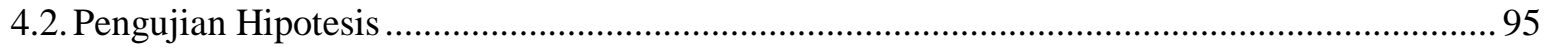

4.3. Pengaruh Langsung, Tidak Langsung dan Pengaruh Total ....................................................... 98

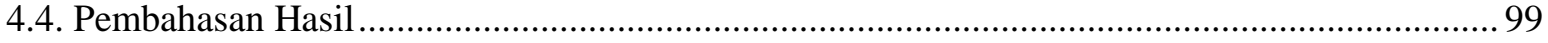

BAB V SIMPULAN DAN SARAN....................................................................102

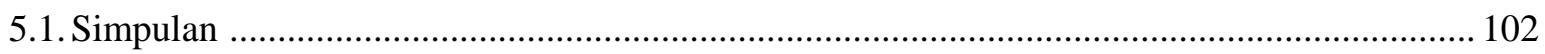

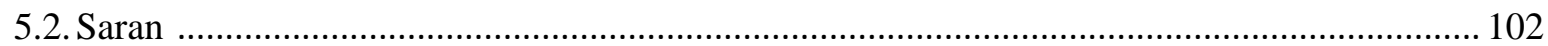

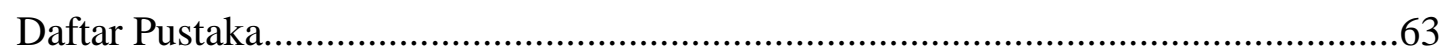




\section{DAFTAR TABEL}

Tabel 2.1. Proses KM .24

Tabel 2.2. Top 20 Keywords based on the Publication Year of Articles ............................... 35

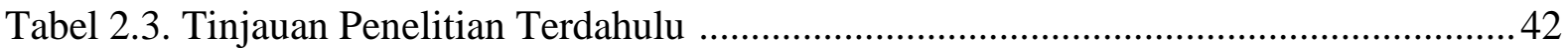

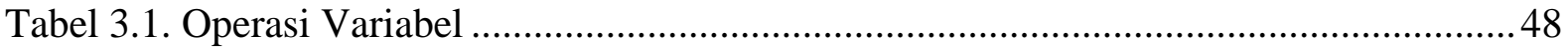

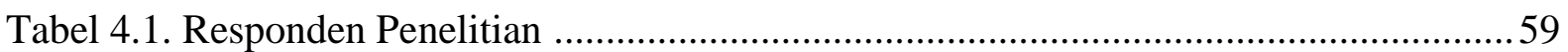

Tabel 4.2. Profil Responden Berdasarkan Sektor Industri Kreatif .........................................59

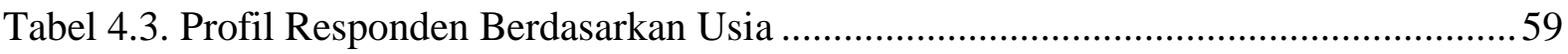

Tabel 4.4. Profil Responden Berdasarkan Jenis Kelamin ....................................................59

Tabel 4.5. Profil Responden Berdasarkan Pendidikan..........................................................59

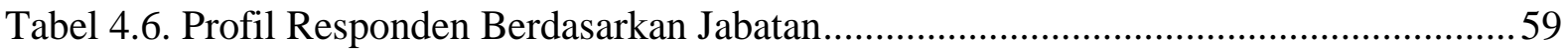

Tabel 4.7. Deskriptif Variabel Kompetensi Teknologi Informasi dan Komunikasi................59

Tabel 4.8. Deskriptif Variabel Manajemen Pengetahuan ....................................................59

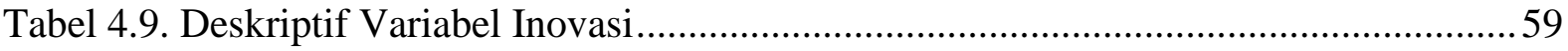

Tabel 4.10. Regression Weights Model_1 CFA Konstruk Eksogen Kompetensi TIK ...........59

Tabel 4.11. Standarized Regression Weights Model_1 CFA Konstruk Eksogen Kompetensi TIK

Tabel 4.12. Standarized Regression Weights Model_2 CFA Konstruk Eksogen Kompetensi TIK

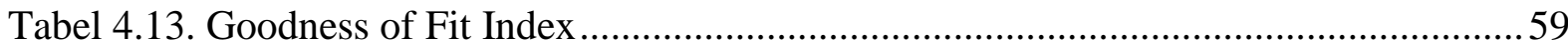

Tabel 4.14. Hasil Pengujian Model_3 CFA Konstruk Eksogen Kompetensi TIK ..................59

Tabel 4.15. Standarized Regression Weights Model_1 CFA Konstruk Endogen Manajemen

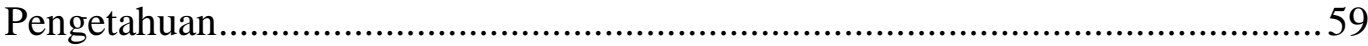

Tabel 4.16. Standarized Regression Weights Model_2 CFA Konstruk Endogen Manajemen

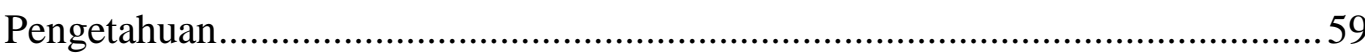

Tabel 4.17. Hasil Pengujian Model_3 CFA Konstruk Endogen Manajemen Pengetahuan ....59

Tabel 4.18. Standarized Regression Weights Model_1 CFA Konstruk Endogen Inovasi ......59

Tabel 4.19. Standarized Regression Weights Model_2 CFA Konstruk Endogen Inovasi ......59

Tabel 4.20. Regression Weights Model Full Model_1 ...........................................................59

Tabel 4.21. Standarized Regression Weights Model_1 Full Model_1 ..................................59

Tabel 4.22. Regression Weights Model Full Model_2 .........................................................59

Tabel 4.23. Standarized Regression Weights Model Full Model_2 .......................................59

Tabel 4.24. Hasil Pengujian Full Model_3 ……....................................................................59 
Tabel 4.25. Assesment of Normality Full Model_3 …..........................................................59

Tabel 4.26. Evaluasi Outliers Model Full Model_3 …...........................................................59

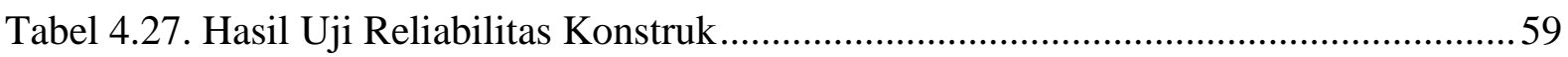

Tabel 4.28. Korelasi antar Konstruk dan Akar Kuadrat AVE Konstruk ...............................59

Tabel 4.29. Regression Weights Model Full Model_3 ...........................................................59

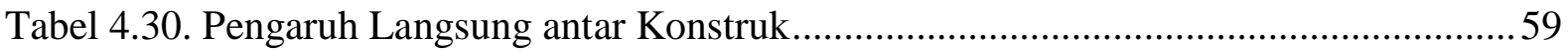

Tabel 4.31. Pengaruh Tidak Langsung antar Konstruk .........................................................59

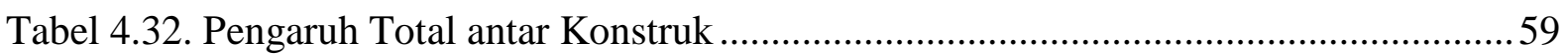




\section{DAFTAR GAMBAR}

Gambar 2.1. Knowledge Pyramid........................................................................................13

Gambar 2.2. Explicit, Tacit, dan Implicit Knowledge ........................................................ 14

Gambar 2.3. Declarative \& Procedural Knowledge ............................................................. 16

Gambar 2.4. A Framework for Thinking About the Knowledge in KM .............................. 17

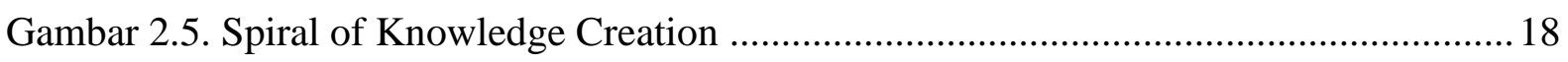

Gambar 2.6. Major \& Minor Categories Related to KM ......................................................22

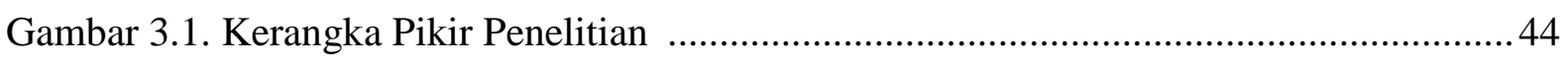

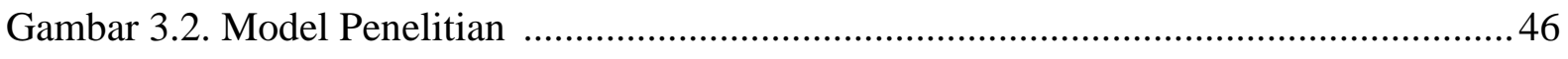

Gambar 4.1. Profil Responden Berdasarkan Sektor Industri Kreatif .................................... 46

Gambar 4.2. Model_1 CFA Konstruk Eksogen Kompetensi TIK ....................................... 46

Gambar 4.3. Model_2 CFA Konstruk Eksogen Kompetensi TIK ...................................... 46

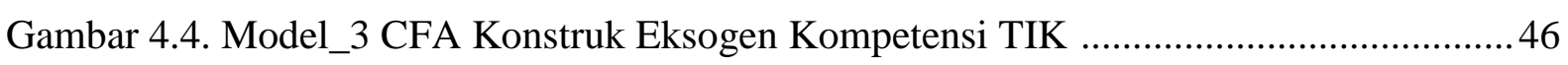

Gambar 4.5. Model_1 CFA Konstruk Endogen Manajemen Pengetahuan .......................... 46

Gambar 4.6. Model_2 CFA Konstruk Endogen Manajemen Pengetahuan ........................... 46

Gambar 4.7. Model_3 CFA Konstruk Endogen Manajemen Pengetahuan ........................... 46

Gambar 4.8. Model_1 CFA Konstruk Endogen Inovasi..................................................... 46

Gambar 4.9. Model_2 CFA Konstruk Endogen Inovasi.................................................... 46

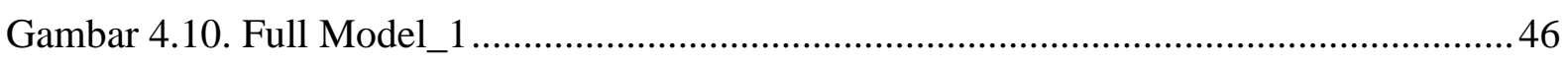

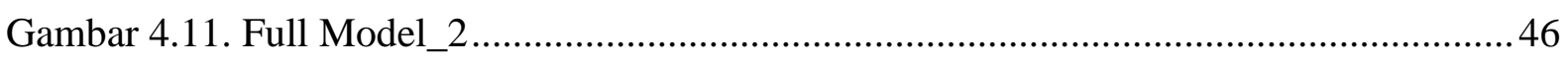

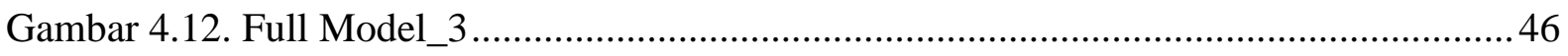




\section{BAB I \\ PENDAHULUAN}

\subsection{Latar Belakang}

Sejak tahun 1990an, peran penting Manajemen Pengetahuan (Knowledge Management/KM) untuk menciptakan keunggulan kompetitif suatu organisasi, baik organisasi swasta maupun pemerintah, telah diakui. Dalam KM, dilakukan suatu pengelolaan yang menggunakan pengetahuan sebagai aset utama. Di Jepang kita bisa saksikan bagaimana Honda, Canon, dan Fuji mampu menjadi perusahaan yang menghasilkan produk yang inovatif yang laku dipasaran dengan menggunakan KM sebagai strategi terdepannya (Rory L.Chase, 2003). Kita juga ingat bagaimana Nortel (Perusahaan telekomunikasi asal Canada) yang pada masa jayanya, berhasil menjadi pemimpin di bidang telekomunikasi lewat transformasi proses bisnisnya, sehingga mampu meningkatkan jumlah inovasi dalam produk-produknya yang juga sangat fenomenal (Massey, Montoya, O’Driscoll, 2002). Hal ini sesuai dengan apa yang diungkapkan Paul Martin, tentang pengetahuan dan inovasi (knowledge \& innovation); menurutnya, pengetahuan dan inovasi adalah bahan baku baru ekonomi abad ke-21. Pengetahuan dan inovasi adalah kunci untuk sebuah negara yang bisa bersaing ke depan, bagaikan dua sisi dari mata uang yang sama - yang menjadi kunci kesuksesan masa depan (Feldman, Stewart, 2006).

Di Indonesia sudah ada beberapa organisasi besar yang telah melakukan implementasi KM. Dimulai oleh Teleos-The KNOW Network yang merupakan badan penelitian mandiri di bidang knowledge management dan intellectual capital, dan Indonesian Most Admired Knowledge Enterpise (MAKE) Study yang merupakan 
studi tentang perusahaan berbasis pengetahuan yang paling dikagumi di Indonesia, kegiatan ini diselenggarakan oleh Dunamis Organization Services, dan sejak tahun 2005 telah beberapa kali mengadakan kompetisi bagaimana penerapan KM di Indonesia. Dari data ini kita bisa melihat oraganisasi-organisasi yang masuk nominasi; diantaranya data nominator dan pemenang tahun 2013 adalah Bank Mandiri, Bank Syariah Mandiri, Bank CIMB Niaga, Binus University, Pertamina, Perusahaan Listrik Negara (PLN), Sinar Mas Argo Resources \& Technologies, TELKOM Indonesia (Dunamis, 2013).

KM terdiri dari tiga proses utama, yaitu yaitu: knowledge generation, knowledge transfer, dan knowledge codification and storage (Lopez, Peon, Ordas, 2009). Knowledge generation dapat didefinisikan sebagai proses dimana perusahaan memperoleh pengetahuan, baik dari luar perusahaan atau internal (Lee dan Hong, 2002: McCann dan Buckner, 2004). Tujuannya adalah untuk memperoleh pengetahuan baru dan lebih baik yang membantu organisasi meningkatkan daya saing (Wiig, 1997). Knowledge transfer mengacu pada proses dimana organisasi men-share knowledge antar unit dan anggota, mempromosikan pemahaman baru (Wiig, 1997; Alavi dan Leidner, 2001). Hal ini penting bagi perusahaan untuk mengembangkan desain jaringan interaksi informatif yang memungkinkan individu yang beragam, budaya, dan lokasi geografis, tidak hanya untuk mengakses informasi yang sama tetapi juga untuk menyatu melalui jaringan untuk melakukan suatu proyek tertentu. Knowledge codification and storage merupakan aspek yang sangat penting dalam manajemen pengetahuan yang efektif (Levitt dan March: 1988; Huber: 1991, Cross dan Baird, 2000). Pengetahuan yang ada harus ditangkap, dikodifikasikan, disajikan dan dimasukkan ke penyimpanan dengan cara terstruktur, sehingga dapat digunakan 
kembali kemudian (Choi et al., 2008). Namun, sangat penting untuk diingat bahwa pengetahuan organisasi tersebar di seluruh organisasi. Ia ditemukan di lokasi yang berbeda, dalam pikiran orang, dalam proses organisasi, dan dalam budaya organisasi, tertanam dalam artefak dan prosedur yang berbeda, dan disimpan dalam media yang berbeda seperti media cetak, disk dan media optik (Bhatt, 2001). Dengan demikian, beberapa penulis menyarankan bahwa menangkap, mengkodifikasi dan menyimpan pengetahuan adalah aspek yang paling menantang dari manajemen pengetahuan.

Penerapan dan penggunaan Teknologi Informasi dan Komunikasi (TIK) dalam mendukung KM dalam organisasi secara umum dan dalam Industri Kreatif secara khusus menjadi tantangan yang membutuhkan pendekatan dan penelitian konseptual baru. TIK yang digunakan dalam KM memberikan potensi yang sangat tinggi dalam meningkatkan akses terhadap knowledge dikombinasikan dengan tantangan bagaimana mengelola akses (Hawkins, 2000). Selain itu TIK menjanjikan peningkatan kualitas, efisiensi, dan efektivitas proses dan menarik solusi dalam memberikan kontribusi untuk berbagai bidang disiplin ilmu termasuk manajemen, information retrieval, artificial intelligence, dan perilaku organisasi.

Adopsi penggunaan TIK untuk meningkatkan dan memfasilitasi KM telah membawa pada fokus urgensitas kebutuhan akan metode baru, tools dan teknik untuk perkembangan KM systems frameworks, knowledge processes dan knowledge technologies dalam mendukung manajemen knowledge yang efektif untuk meningkatkan innovasi organisasi. 
Saat ini muncul paradigma baru, dimana orang percaya bahwa kedua komponen, baik teknologi atau kultur adalah sama-sama penting. Meniadakan salah satu dipercaya mengakibatkan KM tidak dapat secara maksimal mencapai misinya. Kelompok ini percaya KM sebagai socio-technical system (Svetlana, 2010; Grundstein, Rosenthal, 2007), yang artinya KM wajib mengakomodasi kedua komponen teknologi dan kultur. KM tidak dapat meniadakan teknologi dan tidak juga dapat meniadakan kultur.

Melihat KM sebagai socio-technical system akan mengakomodasi people, proces dan technology sebagai elemen penting yang harus dipertimbangkan dalam implementasinya. Dengan memandang KM sebagai socio-technical system, teknologi akan berperan sebagai katalis yang memungkinkan dan menfasilitasi terselenggaranya pengembangan, tranfer dan pemanfaatan knolwedge, yang akan berkontribusi kepada improvement dan inovasi.

\subsection{Perumusan Masalah}

Tidak ada industri, tidak ada perusahaan yang tetap berada di puncak tanpa tetap berinovasi (Zehir, 2008). Upaya inovatif meliputi mencari, dan menemukan, pengujian, dan pengembangan teknologi baru, produk atau jasa baru, prosedur produksi baru, dan struktur organisasi yang baru. Inovasi adalah tentang melakukan ide (Borghini, 2005). Prosedur Inovasi yang menguntungkan tergantung pada pengetahuan (Gloet \& Terziovski, 2004), khususnya pada pengetahuan tacit (Leonard \& Sensiper, 1998). Pengetahuan baru dan berharga dibuat dan berubah menjadi produk, layanan dan prosedur (Choy, Yew, \& Lin: 2006), dengan mengkonversi pengetahuan umum menjadi pengetahuan khusus. Secara umum bisa ditegaskan, 
manajemen pengetahuan, dapat mempengaruhi kinerja organisasi dalam sejumlah cara yang berbeda (Von Krogh et al., 2000). Inovasi merupakan salah satu hasil utama dari KM.

Pada tempat yang lain, Teknologi Informasi dan Komunikasi (TIK) telah menjadi topik sentral pada literatur KM (Hayes dan Walsham, 2003). TIK telah terkait erat dengan perkembangan sebagian besar inisiatif KM. Diperkirakan bahwa hampir $70 \%$ dari publikasi pada KM fokus pada desain sistem TI (Franco dan Mariano, 2007). Jika inovasi merupakan salah satu hasil utama dari KM dan TIK telah menjadi topik sentral pada KM, artinya ada hubungan tidak langsung atara TIK dengan inovasi (Zehir, 2008).

Oleh karena itu berdasarkan kerangka di atas, rumusan masalah kedua dan ketiga yang dapat ditarik kemudian adalah:

1) Apakah Kompetensi TIK memiliki pengaruh positif terhadap Manajemen Pengetahuan (Knowledge Management) ?

2) Apakah Manajemen Pengetahuan (Knowledge Management) memiliki pengaruh positif terhadap Inovasi ?

3) Apakah Kompetensi TIK memiliki pengaruh positif terhadap Inovasi melalui Manajemen Pengetahuan?

\subsection{Tujuan dan Manfaat}

Penerapan dan penggunaan TIK dalam mendukung KM dalam organisasi secara umum dan dalam Industri Kreatif secara khusus menjadi tantangan yang membutuhkan pendekatan dan penelitian konseptual baru. TIK yang digunakan dalam 
KM memberikan potensi yang sangat tinggi dalam meningkatkan proses KM. Selanjutnya proses KM pada sebuah organisasi secara langsung akan berdampak pada bagaimana praktek KM yang dilakukan organisasi tersebut. Praktek KM yang baik diharapkan dapat mendukung inovasi suatu oraganisasi. Saat ini keberhasilan inovasi menjadi lebih penting. Setelah bertahun-tahun restrukturisasi dan pemotongan biaya untuk mendapatkan kembali profitabilitas, banyak perusahaan dipaksa untuk memperbaharui portofolio produk mereka. Namun, itu tak cukup, dibutuhkan inovasi yang berkelanjutan; hanya dengan produk baru, mereka dapat mempertahankan posisi kompetitif mereka dengan meningkatkan pendapatan dan laba, yang menyebabkan nilai perusahaan ditingkatkan. Tapi apakah perusahaan memiliki kondisi yang tepat dan lingkungan yang mendukung untuk memimpin mereka untuk sukses dalam inovasi yang maksimal? Apakah organisasi memahami pemicu yang tepat dan kunci untuk mengoptimalkan keberhasilan inovasi mereka? Penulis menekankan hubungannya dengan peran KM sebagai salah satu tuas kunci untuk mencapai keberhasilan inovasi ini.

Oleh karena itu, tujuan penelitian ini adalah :

1. Mengukur bagaimana pengaruh kompetensi TIK terhadap proses Manajemen Pengetahuan pada industri kreatif

2. Mengukur bagaimana pengaruh Knowledge Management terhadap Inovasi

3. Mengukur bagaimana pengaruh kompetensi TIK terhadap inovasi melalui Manajemen Pengetahuan

Sedangkan manfaat langsung dari penelitian ini bagi pelaku Industri KreatifBatam adalah peneliti berharap dapat memberikan masukan pandangan baru tentang 
bagaimana peran Kompetensi TIK terhadap asset knowledge untuk inovasi yang terus-menerus.

Selain itu, hal penting dari manfaat penelitian ini adalah membawa KM ke Batam, Batam sebagai kota Industri, tentu apabila di belahan dunia lain KM telah memberikan kontribusi yang menonjol bagi keberlangsungan organisasi demikian juga untuk industri di Batam.

\subsection{Batasan Masalah}

Batasan Masalah dalam penelitian ini adalah pada variabel Kompetensi TIK, Knowledge Management dan Inovasi; yang akan meliputi kompetensi TIK, Tiga proses utama KM: knowledge generation, knowledge transfer, dan knowledge codification and storage, sampai pada pengaruhnya pada inovasi. Kesemuanya itu pada penelitian ini akan berfokus pada data-data dan lingkungan yang terjadi pada industri kreatif di kota Batam, khususnya pada lima subsektor yaitu: industri radio, stasiun televisi, arsitektur, publishing, dan IT software and computer services, yang semua berbasis di Batam. 


\section{BAB II \\ LANDASAN TEORI}

Dalam penelitian ini terdapat teori-teori untuk melandasi dan mendukung kegiatan penelitian. Teori-teori yang dipakai adalah teori-teori yang sudah diuji melalui penelitianpenelitian sebelumnya sehingga dapat dipakai untuk melakukan penelitian ini. Teori mengenai knowledge management, Teknologi Informasi dan Komunikasi (TIK), dan Inovasi, akan dibahas dalam bab ini.

\subsection{Knowledge Management}

Knowledge Management (KM) sering diartikan secara umum tentang bagaimana mendapatkan pengetahuan (knowledge) yang benar, kepada orang yang tepat dan pada waktu yang tepat. Sebagian orang lain mengartikan KM adalah bagaimana organisasi mengelola pengetahuan dan bagaimana mengoptimalkannya dalam mencapai tujuan organisai. KM dapat mempengaruhi kinerja organisasi dalam sejumlah cara yang berbeda (Von Krogh et al., 2000). Inovasi merupakan salah satu hasil utama dari KM.

Mendefinisikan KM bukanlah hal yang sederhana. KM bukan berbicara tentang teknologi, meskipun teknologi harus dimanfaatkan sebagai enabler. KM membutuhkan budaya (culture) yang dapat mempromosikan sebuah kepercayaan dan semangat kolektif tentang berbagi dan berpikir; tetapi budaya saja tidaklah cukup membuat praktek KM menjadi sukses. Frappaolo (2006) berpendapat bahwa KM adalah leveraging dari kebijaksanaan kolektif untuk meningkatkan respon dan inovasi. 


\subsubsection{Definisi Knowledge}

Knowledge (pengetahuan) telah berkembang menjadi salah satu istilah yang paling cepat berkembang di bidang manajemen, baik dalam organisasi akademis dan bisnis. Knowledge telah memainkan beberapa peran penting dalam pengembangan utama organisasi. Drucker (1995) menyatakan bahwa "Knowledge adalah satusatunya sumber informasi yang berarti ekonomi". Namun, Quintas dan Lefrere (1997) mengatakan bahwa, proses dimana Knowledge diciptakan atau diperoleh, ditransfer atau dikomunikasikan, diterapkan atau digunakan, mengharuskan suatu pengelolaan secara efektif untuk organisasi maupun masyarakat.

Dalam kehidupan sehari-hari kita menggunakan knowledge sepanjang waktu. Terkadang kita mengartikannya sebagai knowledge, sedangkan pada kesempatan lainnya kita sering menyebutnya wisdom (kebijaksanaan). Pada banyak kesempatan lain juga, kita bahkan menggunakannya untuk merujuk pada information (informasi). Bagian dari kesulitan mendefinisikan knowledge muncul dari hubungannya dengan dua konsep lainnya, yaitu data dan informasi. Kedua istilah ini sering dianggap sebagai denominasi dibawah knowledge, tetapi hubungan yang tepat sangat bervariasi dari satu contoh ke yang lain.

Selain Tom Davenport dan Laurence Prusak (2000) yang membedakan data, information dan knowledge, Frost (2013) juga mempertegas dengan memberikan penekanan sebagai berikut: data adalah fakta dan angka yang menyampaikan sesuatu yang spesifik, tapi yang tidak terorganisir dengan cara apapun dan yang tidak memberikan informasi lebih lanjut mengenai pola, konteks, dll. Data yang menjadi informasi harus dikontekstualisasikan, dikategorikan, dihitung dan disarikan. Oleh karena itu, informasi melukiskan gambaran yang lebih besar; yaitu data dengan 
relevansi dan tujuan. Informasi dapat menyampaikan tren yang sedang terjadi untuk jangka waktu tertentu. Pada dasarnya informasi ditemukan dalam jawaban atas pertanyaan yang dimulai dengan kata-kata seperti: siapa, apa, di mana, kapan, dan berapa banyak (Ackoff 1999). TIK biasanya berharga dalam kapasitas untuk mengubah data menjadi informasi, khususnya di perusahaan-perusahaan besar yang menghasilkan sejumlah besar data di beberapa departemen dan fungsi. Otak manusia terutama diperlukan untuk membantu dalam kontekstualisasi. Knowledge berhubungan erat dengan melakukan dan menunjukkan pengetahuan dan pemahaman (know-how). Dalam bukunya Working Knowledge, Davenport dan Prusak (1998) mendefinisikan Knowledge sebagai berikut: "Knowledge is a fluid mix of framed experience, values,contextual information, and expert insight that provides a framework for evaluating and incorporating new experiences and information. It originates and is applied in the minds of knowers. In organisations, it often becomes embedded not only in documents and repositories but also in organisational routines, processes, practices, and norms"(p.5). Knowledge ibarat campuran "cairan pengalaman", nilai-nilai, informasi kontekstual, dan wawasan mendalam yang memberikan kerangka untuk mengevaluasi dan menggabungkan pengalaman dan informasi baru. Knowledge berasal dan diterapkan dalam pikiran seseorang. Dalam organisasi, Knowledge sering terjadi terdapat bukan hanya dalam dokumen dan repositori tetapi juga dalam rutinitas organisasi, proses, praktik, dan norma-norma.

Dengan demikian akan terlihat bahwa meskipun Davenport, Prusak dan Frost membedakan antara data, informasi dan pengetahuan, pada kenyataannya definisi pengetahuan menggabungkan informasi, menampung gagasan bahwa pengetahuan adalah suatu keadaan dan, pada saat yang sama, mengakomodasi pandangan bahwa 
pengetahuan ada terlepas dari seseorang (knowers). Hal ini juga mengakomodasi gagasan dari pengetahuan sebagai kapasitas untuk bertindak atau melakukan sesuatu.

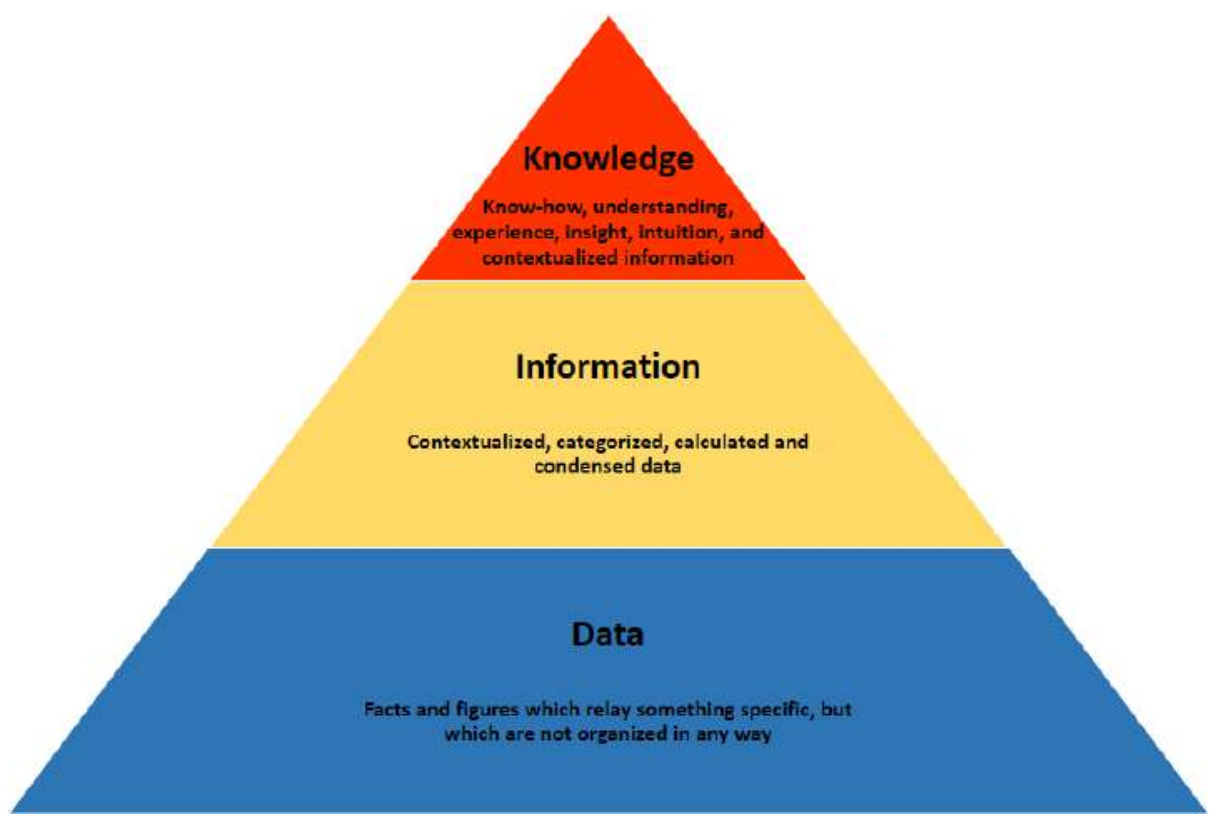

Gambar 2.1 "Knowledge Pyramid" (sumber: Frost, 2010)

Dari penjelasan di atas, dapat peneliti simpulkan bahwa, agar KM berhasil, maka orang perlu pemahaman yang konprehensif tentang apa yang merupakan pengetahuan. Batas-batas yang jelas tentang apa itu pengetahuan, informasi dan data sebagaimana penjelasan di atas akan sangat membantu kita untuk melangkah lebih jauh dan melihat bentuk-bentuk di mana pengetahuan berada, dan bagaimana dapat mengaksesnya dengan berbagai cara, kemudian bagaimana membaginya (share).

Frost (2013) menulis bahwa selama berabad-abad banyak upaya telah dilakukan untuk mengklasifikasikan pengetahuan, dan berbagai bidang telah berfokus pada dimensi yang berbeda. Hal ini telah mengakibatkan berbagai klasifikasi dan perbedaan yang berbasis filsafat dan bahkan agama.

Nonaka pada dasarnya membagi pengetahuan di dalam organisasi ada dua macam (Nonaka \& Takeuchi, 1995; Nonaka \& Konno, 1998) yaitu pengetahuan tasit 
dan eksplisit (tacit and explicit). Kedua macam pengetahuan tersebut bersifat kontinum (Schutt, 2003). Pengetahuan eksplisit dapat diekspresikan dalam katakata dan angka-angka yang dapat disajikan dalam bentuk data, formula ilmiah, spesifikasi, manual dan sebagainya. Jenis pengetahuan ini siap untuk ditranmisikan antar individu secara formal dan sistematik. Pengetahuan tasit bersifat personal dan sulit dilakukan formalisasi, sehingga sulit untuk dikomunikasikan dan dibagikan kepada pihak lain. Pengetahuan tasit berisi insight subjektif, intuitif, dan berakar dari perilaku dan pengalaman (Nonaka \& Takeuchi, 1995; Nonaka \& Konno, 1998; Debowski, 2006 p.17-18).

Mempertegas dua macam tipe knowledge, Nickols (2000) menambahkan tentang pengetahuan implisit (implicit knowledge) yaitu pengetahuan yang sebenarnya dapat diartikulasikan tetapi belum dilakukan. Keberadaannya tersirat atau disimpulkan dari perilaku atau kinerja yang dapat diamati. Pengetahuan implisit secara khas dikendalikan oleh tenaga ahli. Bagaimanapun, tidak sama dengan pengetahuan tasit, pengetahuan implisit dapat diambil dari orang yang ahli melalui suatu proses yang disebut rancang-bangun pengetahuan (knowledge engineering). Untuk lebih jelasnya bagaimana pengetahuan eksplisit, tasit dan implisit dapat dilihat pada Gambar 2.2 ini:

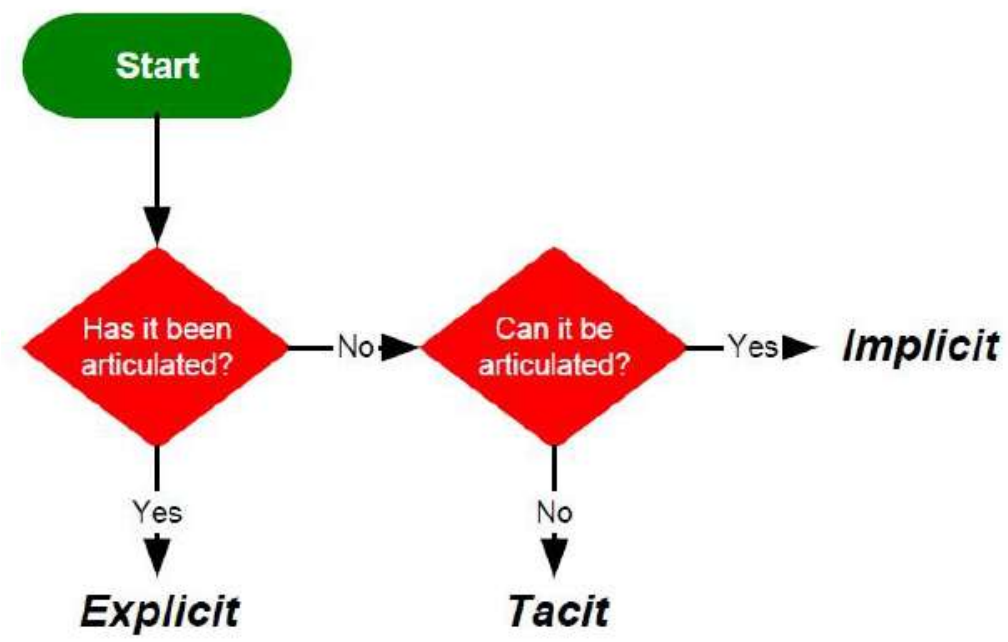


Pengetahuan eksplisit, tasit dan implisit, bukanlah satu-satunya pembagian yang digunakan dalam menjabarkan pengetahuan. Psikolog kognitif memilah pengetahuan kedalam dua kategori: deklaratif dan prosedural (declarative and procedural), beberapa literatur menambahkan strategis (strategic) sebagai kategori yang ketiga (Nickols, 2000).

Pengetahuan deklaratif memiliki banyak kesamaan dengan pengetahuan eksplisit bahwa pengetahuan deklaratif terdiri dari deskripsi fakta dan hal-hal atau metode dan prosedur. Pengetahuan deklaratif berbicara tentang "mengetahui apa" (know-what) meliputi definisi dan fakta ilmu, kebanyakan dalam bentuk pernyataan, term, deskripsi atau data, misalnya kepadatan air adalah 1 gram per milimeter pada 4 per seratus derajat dan pada satu atmosfir tekanan (Shavelson dkk., 2003). Untuk sebagian besar tujuan praktis, pengetahuan deklaratif dan pengetahuan eksplisit dapat diperlakukan sebagai sinonim. Hal ini karena semua pengetahuan deklaratif adalah pengetahuan eksplisit, yaitu, itu adalah pengetahuan yang dapat dan telah diartikulasikan.

Pengetahuan prosedural adalah bahwa pengetahuan tentang bagaimana melakukan sesuatu (know-how), misalnya mengetahui bagaimana mengukur kepadatan sebuah obyek atau bagaimana membuat grafik hubungan antara sudut miring pesawat dan tenaga yang dibutuhkan untuk menerbangkan sebuah obyek ke atas. Pengetahuan prosedural meliputi aturan ke atas. Pengetahuan prosedural meliputi aturan- aturan jika-maka atau serangkaian langkah yang dapat digunakan untuk mencapai sebuah tujuan tertentu (Shavelson dkk., 2003). 
Facts \&

Gambar 2.3 Declarative \& Procedural Knowledge (Describing vs Doing) (sumber: Nickols, 2000)

Salah satu pandangan pengetahuan prosedural adalah bahwa pengetahuan yang memanifestasikan dirinya dalam perbuatan sesuatu. Karena itu tercermin pada motor atau keterampilan manual dan dalam keterampilan kognitif atau mental. Sebagaimana diagram pada Gambar 2.3 menunjukkan, hubungan pengetahuan deklaratif untuk "menggambarkan atau menjelaskan" dan hubungan pengetahuan prosedural untuk "melakukan." Dengan demikian, kita bisa simpulkan semua pengetahuan prosedural sebagai tasit seperti juga semua pengetahuan deklaratif adalah eksplisit.

Pengetahuan strategis (strategic knowledge) adalah istilah yang digunakan oleh beberapa orang untuk merujuk pada apa yang mungkin disebut "tahu-kapan, dimana dan bagaimana" (know-when, know-where, know-how), meliputi domain pengetahuan tertentu dan strategi seperti perencanaan dan pemecahan masalah (Shavelson dkk., 2003). 
Integrasi diagram sebagaimana pada Gambar 2.2 dan Gambar 2.3 dapat dilihat pada Gambar 2.4, yaitu pengetahuan eksplisit, tasit, implisit, deklaratif dan prosedural.

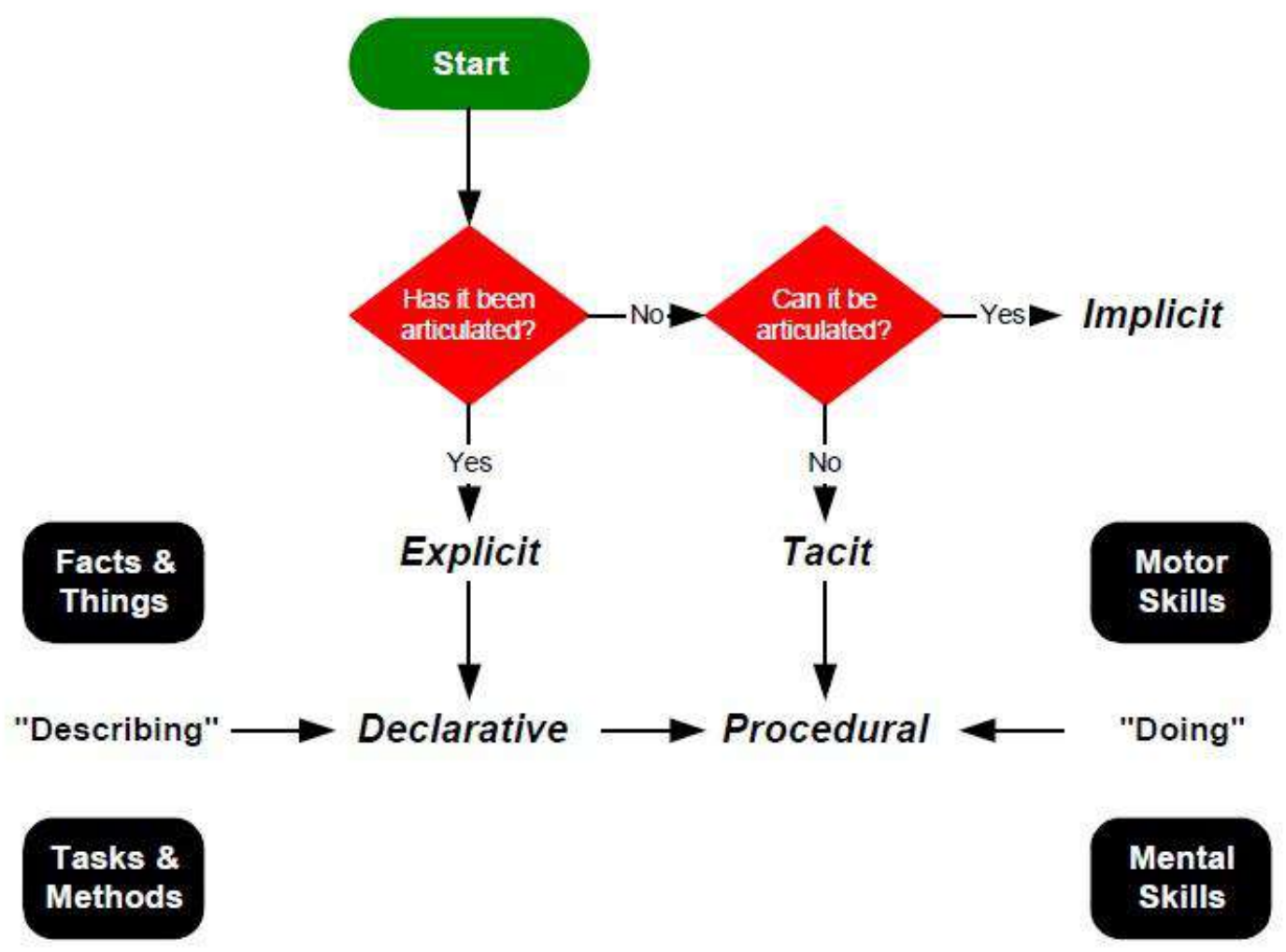

Gambar 2.4 A Framework for Thinking About the Knowledge in Knowledge Management (sumber: Nickols, 2000)

Panah yang menghubungkan deklaratif dan prosedural menunjukkan bahwa kita sering mengembangkan pengetahuan prosedural atau kemampuan untuk melakukan sesuatu sebagai hasil dari atau dimulai dengan pengetahuan deklaratif. Dengan kata lain, kita sering terlebih dahulu "tahu tentang" (know-about) sebelum kita "tahu bagaimana" (know-how).

Tantangan terbesar yang dihadapi oleh organisasi-organisasi adalah bagaimana mengkonversi tacit knowledge menuju explicit knowledge, atau sebaliknya. Organisasi dituntut untuk mampu menterjemahkan pengetahuan yang eksis di individu, kelompok atau tim, dan organisasi menjadi nyata dalam bentuk 
produk-produk dan jasa-jasa yang dihasilkan. Agar konversi dapat berjalan dengan baik, Nonaka dan Takeuchi (1995) memperkenalkan empat pola dasar penciptaan pengetahuan yang dikenal dengan The Spiral of Knowledge. Lihat Gambar 2.5 berikut:

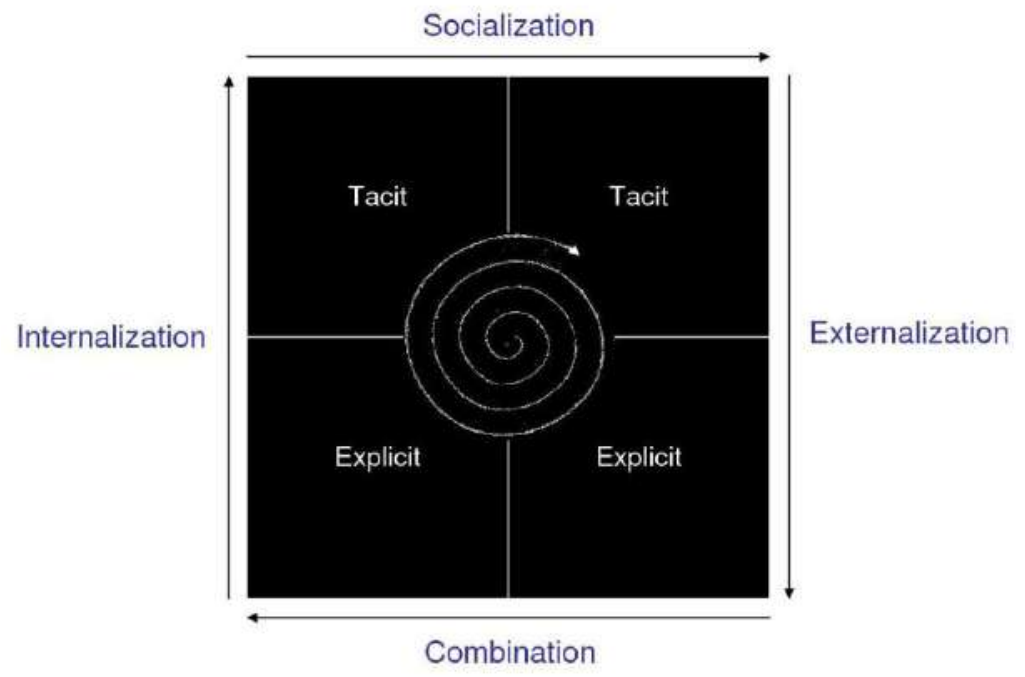

Gambar 2.5 Spiral of Knowledge Creation (sumber: Nonaka \& Takeuchi 1996)

Sosialisasi (socialization) menjelaskan saling berbagi antar tacit knowledge, umumnya tanpa melihat hal-hal formal, misalnya sharing budaya organisasi antara anggota organisasi yang lama dengan anggota yang masih baru, dengan tujuan agar anggota yang masih baru mampu beradaptasi dengan budaya organisasi yang telah melekat pada organisasi tersebut. Eksternalisasi/artikulasi (externalization) artinya kengkonversi tacit knowledge menjadi explicit knowledge, umumnya menggunakan metaphor-metafor yang dipahami bersama. Misalnya, hasil pengamatan dan observasi terhadap mesin baru diubah dalam bentuk tertulis yang mudah dipahami dan dapat didiskusikan bersama rekan-rekan kerja yang lain. Sedangkan kombinasi (combination) adalah mengkombinasikan antar explicit knowledge yang dipunyai oleh individu lain dengan explicit knowledge yang dipunyai oleh diri sendiri. Internalisasi (internalization) berarti mengkonversi explicit knowledge menuju tacit knowledge. 
Istilah yang paling popular untuk menjelaskan internalisasi adalah learning by doing. Misalnya dengan pengalaman mengoperasikan mesin baru dapat meningkatkan pemahaman tacit knowledge.

Debowski (2006, p.170) menjelaskan mengenai hal penting yang perlu diperhatikan dari Knowledge Management adalah bahwa tujuan dari Knowledge Management adalah untuk mengembangkan strategi pengetahuan yang memfasilitasi akses yang mudah terhadap pengetahuan yang berharga. Oleh karena itu, sangat penting untuk dapat mengklarifikasi pengetahuan apa yang penting sehingga karyawan memiliki kesadaran untuk mengatur pengetahuannya secara tepat baik itu bagaimana mendistribusikannya maupun menggunakannya.

\subsubsection{Definisi Knowledge Management (KM)}

KM adalah tentang bagaimana membuat pengetahuan yang tepat (right knowledge) tersedia untuk orang yang tepat. $\mathrm{KM}$ adalah tentang memastikan bahwa organisasi dapat belajar, dan bahwa dengan hal itu, organisasi akan dapat mengambil dan menggunakan aset pengetahuan dalam aplikasi saat ini sebagaimana yang mereka butuhkan atau dalam kata-kata Peter Drucker adalah "koordinasi dan eksploitasi sumber daya pengetahuan (knowledge resources) organisasi, dalam rangka menciptakan manfaat dan keunggulan kompetitif" (Drucker 1999).

Berbicara KM, perbedaan pendapat kadang-kadang terjadi dalam hubungannya dengan penciptaan pengetahuan baru. Wellman (2009) membatasi ruang lingkup KM untuk sesuatu yang dipelajari (leassons learned) dan teknik yang digunakan untuk memanajemen apa yang sudah diketahui. Dia berpendapat bahwa penciptaan pengetahuan sering dianggap sebagai disiplin yang terpisah dan umumnya berada di bawah manajemen inovasi. Bukowitz dan Williams (1999) menghubungkan 
KM langsung dengan kebutuhan taktis dan strategis. Fokusnya adalah pada penggunaan dan peningkatan aset berbasis pengetahuan untuk memungkinkan perusahaan dalam menanggapi dan menyelesaikan suatu masalah.

Definisi yang sama luas disajikan oleh Davenport \& Prusak (2000), yang menyatakan bahwa KM "adalah mengelola pengetahuan korporasi melalui proses sistematis dan organisasional yang ditentukan untuk memperoleh, mengatur, mempertahankan, menerapkan, berbagi dan memperbarui baik pengetahuan tacit dan eksplisit karyawan untuk meningkatkan kinerja organisasi dan menciptakan nilai."

Dari begitu banyak definisi tentang KM, Frost (2000) memberikan definisi integrasi dari beberapa definisi yang telah ada tersebut. Menurutnya KM adalah manajemen yang sistematis dari aset pengetahuan organisasi untuk tujuan menciptakan nilai dan memenuhi persyaratan taktis \& strategis; terdiri dari inisiatif, proses, strategi, dan sistem yang mempertahankan dan meningkatkan penyimpanan, penilaian, berbagi, perbaikan, dan penciptaan pengetahuan.

Lisa Quast, seorang konsultan bisnis menulis dalam majalah Forbes online tanggal 12 Agustus 2012, bahwa ada tiga alasan utama mengapa secara aktif mengapliasikan KM begitu penting untuk keberhasilan perusahaan, yaitu: memfasilitasi kemampuan pengambilan keputusan, membangun organisasi pembelajar (learning organization) dengan membuat "belajar" sebagai rutinitas, merangsang perubahan budaya dan inovasi. Frost (2011) setidaknya menguraikan secara detail manfaat KM sebagai berikut:

1) $\mathrm{KM}$ membantu perusahaan belajar dari kesalahan ataupun keberhasilan masa lalu 
2) Akan lebih baik mengeksploitasi aset pengetahuan yang ada dengan kembali mengimplementasikannya di daerah di mana membutuhkan sesuatu, misalnya menggunakan pengetahuan dari satu departemen untuk meningkatkan atau membuat produk di departemen lain, memodifikasi pengetahuan dari proses masa lalu untuk menciptakan solusi baru, dll

3) KM mempromosikan fokus jangka panjang pada pengembangan kompetensi yang tepat dan keterampilan dan menghapus pengetahuanyang telah usang.

4) KM meningkatkan kemampuan perusahaan untuk berinovasi.

5) $\mathrm{KM}$ meningkatkan kemampuan perusahaan untuk melindungi pengetahuan dan kompetensi kunci agar tidak hilang atau ditiru.

Jadi, apa manfaat KM? KM diperlukan karena menempatkan fokus pada pengetahuan sebagai aset yang sebenarnya, bukan sebagai sesuatu yang tidak berwujud. Dengan demikian, memungkinkan perusahaan untuk melindungi dan memanfaatkan apa yang ia tahu, dan untuk meningkatkan dan memfokuskan upaya pengembangan pengetahuan untuk menyesuaikan apa yang menjadi kebutuhannya.

Dalam studi yang dilakukan Sedighi dan Jalalimanesh (2014) terkait pemetaan riset KM dan aspek-aspek apa saja yang telah menjadi topik-topik penelitian, Gambar 2.6 mencoba memberikan penjelasannya. KM dapat diklasifikasikan ke dalam lima kategori yaitu theoretical and practical aspects, managerial aspects, technological aspects, process KM, dan Organizational-social aspects. 


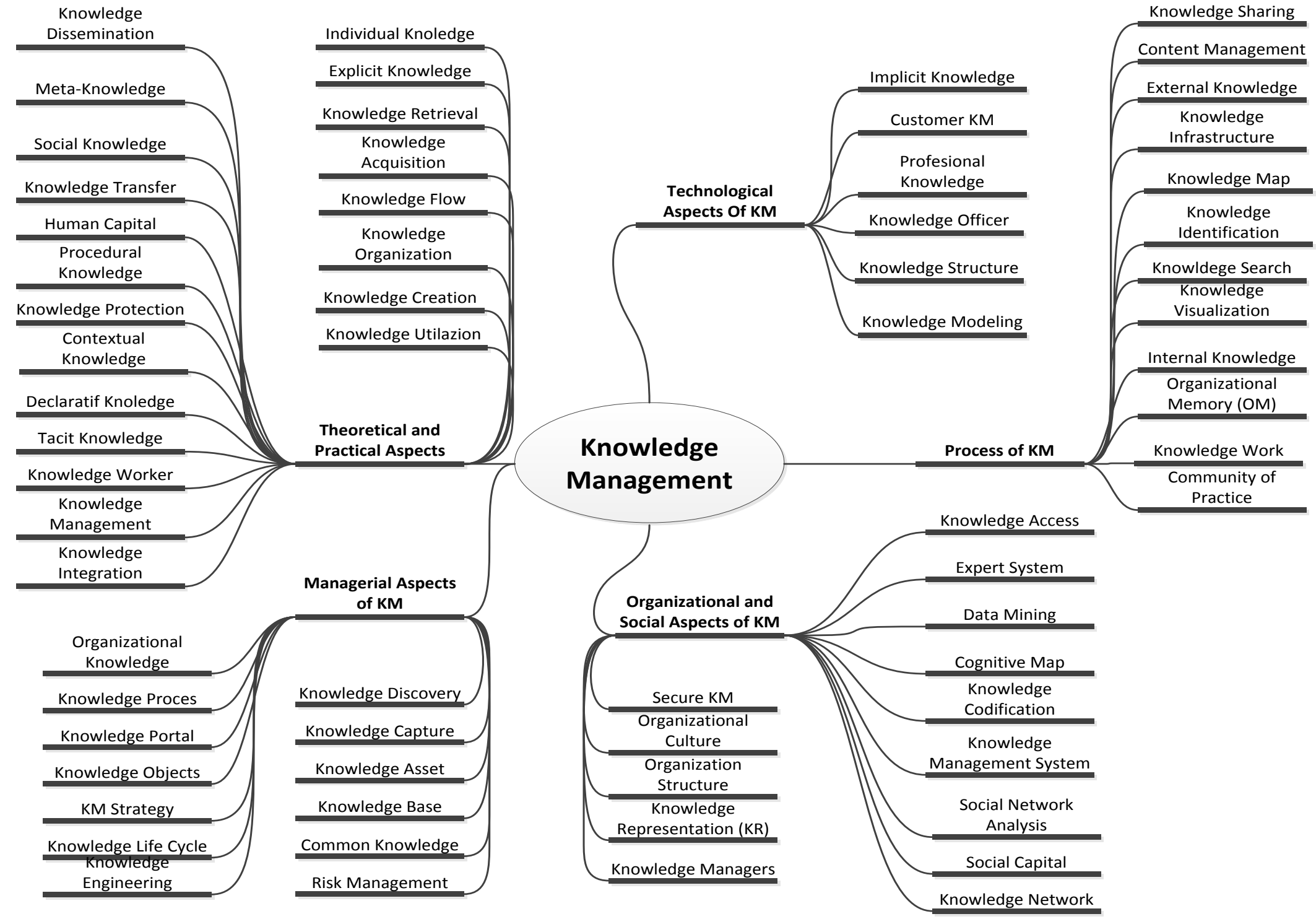

Gambar 2.6. Major \& Minor Categories Related to KM (Sedighi \& Jalalimanesh, 2014) 


\subsubsection{Proses Utama dalam Knowledge Management (KM)}

Setelah panjang lebar kita membahas definisi dari KM dan implikasinya bagi organisasi, sekarang kita akan melihat proses dalam KM. Davenport, Janvenpaa dan Beers (1996) membagi KM dalam empat proses, yaitu menemukan pengetahuan yang ada (finding existing knowledge), menciptakan pengetahuan baru (creating new knowledge), pengemasan pengetahuan yang telah dicipta (packaging knowledge created), keluar menggunakan pengetahuan yang ada (externally using existing knowledge). Teece (1998) membagi KM kedalam delapan proses dasar, menghasilkan pengetahuan baru, mendapatkan pengetahuan yang bernilai dari sumber luar, menggunakan pengetahuan yang dapat diakses untuk mengambil keputusan, menanamkan pengetahuan ke dalam proses, produk dan/ atau jasa, mempresentasikan pengetahuan kedalam dokumen, basis data dan perangkat lunak, memfasilitasi pengetahuan melalui budaya dan insentif, mentransfer pengetahuan ke bagian lain dalam organisasi, dan mengukur nilai dari aset pengetahuan dan/atau dampak dari KM. Penelitian oleh Cranfield University (1998), mengidentifikasi KM dalam sepuluh proses: menciptakan pengetahuan baru, menemukan pengetahuan dari dalam (internal), mendapatkan pengetahuan dari luar (eksternal), memiliki pengetahuan, memproses pengetahuan, menggunakan kembali (re-using) pengetahuan, menerapkan pengetahuan untuk memperoleh keuntungan, meng-update pengetahuan, membagi pengetahuan ke dalam internal organisasi dan membagi pengetahuan ke luar organisasi. Sementara itu Frost (2010) mendefinisikan proses KM kedalam enam bagian yaitu Knowledge Discovery \& Detection, Knowledge Organization \& Assessment, Knowledge Sharing, Knowledge Reuse, Knowledge Creation, Knowledge Acquisition. 
Tabel 2.1 Proses KM

\begin{tabular}{|c|c|}
\hline Auth & KM Processes \\
\hline Wiig (1993) & Creation; Manifestation; Use; Transfer \\
\hline $\begin{array}{l}\text { Nonaka and Takeuchi } \\
\text { (1995) }\end{array}$ & $\begin{array}{l}\text { Socialization; Internalization; } \quad \text { Externalization; } \\
\text { Combination }\end{array}$ \\
\hline $\begin{array}{l}\text { Andersen and APQC } \\
\text { (1996) }\end{array}$ & $\begin{array}{l}\text { Share-create; Identify; Collect; Adapt-organize; } \\
\text { Apply }\end{array}$ \\
\hline $\begin{array}{l}\text { Davenport, Janvenpaa } \\
\text { dan Beers (1996) }\end{array}$ & $\begin{array}{l}\text { Finding existing knowledge, creating new knowledge, } \\
\text { packaging knowledge created, externally using } \\
\text { existing knowledge }\end{array}$ \\
\hline Ruggles (1997) & Generation; Codification; Transfer \\
\hline $\begin{array}{l}\text { Van der Spek and } \\
\text { Spijkervet (1997) }\end{array}$ & Develop; Distribute; Combine; Hold \\
\hline Angus (1998) & Gathering; Organizing; Refining; Disseminating \\
\hline $\begin{array}{l}\text { Holsapple and Joshi } \\
\text { (1998) }\end{array}$ & Acquisition; Selection; Internalization; Use \\
\hline $\begin{array}{l}\text { Cranfield University } \\
\text { (1998) }\end{array}$ & $\begin{array}{l}\text { creating new knowledge, finding knowledge } \\
\text { internally, acquiring knowledge externally, having the } \\
\text { knowledge, processing the knowledge, re-using the } \\
\text { knowledge, applying the knowledge to some benefit, } \\
\text { updating knowledge, sharing knowledge internally, } \\
\text { and sharing knowledge outside the organization. }\end{array}$ \\
\hline (1999) & $\begin{array}{l}\text { Gathering; Storage; Communication; Synthesis; } \\
\text { Dissemination }\end{array}$ \\
\hline $\begin{array}{l}\text { Davenport and Prusak } \\
\text { (2000) }\end{array}$ & Generate; Codify; Transfer \\
\hline $\begin{array}{l}\text { Tannenbaum and } \\
\text { Alliger (2000) }\end{array}$ & Sharing; Accessibility; Assimilation; Application \\
\hline Alavi (2001) & Creating; Storing/Retrieving; Transferring; Applying \\
\hline Heisig (2001) & Create; Store; Distribute; Apply \\
\hline Probst (2002) & $\begin{array}{l}\text { Identification; Acquisition; } \quad \text { Development; } \\
\text { Distribution; Utilization; Preservation }\end{array}$ \\
\hline Tyndale (2002) & Creation; Organization; Distribution; Application \\
\hline Rollet (2003) & $\begin{array}{l}\text { Planning; Creating; Integration; } \\
\text { Transfer; Maintenance; Assessment }\end{array}$ \\
\hline Alan Frost (2010) & $\begin{array}{l}\text { Knowledge Discovery \& Detection, Knowledge } \\
\text { Organization \& Assessment, Knowledge Sharing, } \\
\text { Knowledge Reuse, Knowledge Creation, Knowledge } \\
\text { Acquisition. }\end{array}$ \\
\hline
\end{tabular}


Dari berbagai perbedaan pendapat para ahli dalam proses $\mathrm{KM}$ di atas, $\mathrm{KM}$ dapat dirangkum ke dalam tiga proses utama, sebagaimana digunakan oleh Lopez, Peon, Ordas (2009) dalam penelitiannya, yaitu knowledge generation, knowledge transfer, and knowledge codification and storage.

Penjabaran tentang proses dalam KM ini begitu penting karena akan menjadi kerangka kerja sistematis (systematic framework) yang akan digunakan untuk analisis selanjutnya dalam diskusi peran TIK dalam KM.

Knowledge generation atau penciptaan pengetahuan dapat didefinisikan sebagai proses dimana perusahaan memperoleh pengetahuan, baik dari luar perusahaan atau internal (Lee dan Hong, 2002: McCann dan Buckner: 2004). Tujuannya adalah untuk memperoleh pengetahuan baru dan lebih baik yang membantu organisasi meningkatkan daya saing (Wiig: 1997). Proses penciptaan pengetahuan tidak mewajibkan penciptaan pengetahuan baru. Dalam banyak situasi, organisasi dapat memilih untuk memperoleh pengetahuan dari sumber lain dan mengadopsinya untuk mereka gunakan sendiri (Bhatt, 2000). Organisasi mengkonversi informasi yang mereka kumpulkan dari sumber-sumber internal dan eksternal menjadi pengetahuan melalui proses pembelajaran organisasi mereka dengan menggabungkan dengan pengetahuan mereka sebelumnya, pengalaman, nilainilai dan prosedur organisasi (Hong, 1999). Kemudian, pengetahuan menjadi bagian dari basis pengetahuan organisasi mereka. Inilah sebabnya mengapa pengetahuan diperoleh melalui proses organisasi yang baru dan unik untuk sebuah organisasi tertentu (von Krogh dan Roos, 1996). Organisasi memperoleh pengetahuan dengan berbagai metode, diantaranya imitation, benchmarking, replication, substitution, purchasing, outsourcing dan discovering (Bhatt, 2000; Abou-Zeid, 2002; Zaim, 2000). Meskipun mendapatkan pengetahuan yang berguna adalah alasan penting dari 
generasi pengetahuan, banyak yang menganggap bahwa keunggulan kompetitif yang nyata berasal dari kemampuan organisasi untuk menghasilkan pengetahuan baru dalam organisasi. Dalam konteks ini, faktor kunci keberhasilan telah bergeser dari pengolahan informasi menuju penciptaan pengetahuan dan inovasi yang berkelanjutan (Malhotra, 2000). Proses penciptaan pengetahuan organisasi sangat dipengaruhi oleh proses-proses sosial. Dengan demikian, dalam model penciptaan pengetahuan terkenal Nonaka dan Takeuchi - SECI - tiga dari empat tahap yang berbeda, yaitu, sosialisasi, eksternalisasi dan kombinasi, melibatkan interaksi sosial yang luas di antara anggota organisasi (Chua, 2002).

Knowledge transfer mengacu pada proses dimana organisasi men-share knowledge antar unit dan anggota, mempromosikan pemahaman baru (Wiig, 1997; Alavi dan Leidner, 2001). Hal ini penting bagi perusahaan untuk mengembangkan desain jaringan interaksi informatif yang memungkinkan individu yang beragam, budaya, dan lokasi geografis, tidak hanya untuk mengakses informasi yang sama tetapi juga untuk menyatu melalui jaringan untuk melakukan suatu proyek tertentu. Selain itu, untuk mentransfer pengetahuan tacit, yang membutuhkan lebih banyak interaksi antara individu, perusahaan harus mengembangkan mekanisme yang mendorong dialog dan interaksi (Lave dan Wenger, 1991; Cook and Yanow, 1993; Brown dan Duguid, 1998; Wenger, 1998; Fox, 2000; Gherardi dan Nicolini, 2002). Namun, ini bukan proses yang sederhana, menurut Huber (1991), organisasi tidak tahu apa yang mereka ketahui dan memiliki sistem yang lemah untuk mencari dan mengambil pengetahuan yang berada di dalamnya. Proses komunikasi dan arus informasi secara fundamental mendorong distribusi pengetahuan dalam organisasi. Oleh karena itu proses komunikasi organisasi menjadi sangat penting bagi proses distribusi pengetahuan. Dalam kajian mereka tentang teori komunikasi, Krone, Jablin, 
dan Putname (1987) mengamati bahwa terlepas dari perspektif teoritis tertentu, semua sistem komunikasi terdiri dari komponen-komponen berikut: pengirim (source), pesan, penerima, saluran, dan skema coding/decoding.

Knowledge codification and storage merupakan aspek yang sangat penting dalam manajemen pengetahuan yang efektif (Levitt dan March: 1988; Huber: 1991, Cross dan Baird, 2000). Pengetahuan yang ada harus ditangkap, dikodifikasikan, disajikan dan dimasukkan ke penyimpanan dengan cara terstruktur, sehingga dapat digunakan kembali kemudian (Choi et al., 2008). Namun, sangat penting untuk diingat bahwa pengetahuan organisasi tersebar di seluruh organisasi. Pengetahuan ditemukan di lokasi yang berbeda, dalam pikiran orang, dalam proses organisasi, dan dalam budaya organisasi, tertanam dalam artefak dan prosedur yang berbeda, dan disimpan dalam media yang berbeda seperti media cetak, disk dan media optik (Bhatt, 2001). Dengan demikian, beberapa penulis menyarankan bahwa menangkap, mengkodifikasi dan menyimpan pengetahuan adalah aspek yang paling menantang dari manajemen pengetahuan.

\subsubsection{Praktek Knowledge Management (KM Practices)}

Darroch (2003) mengembangkan tiga skala untuk mengukur perilaku dan praktek untuk masing-masing komponen KM: knowledge acquisition, knowledge dissemination and responsiveness to knowledge. Knowledge acquisition didapatkan dengan tujuh faktor: 1) menghargai sikap dan pendapat karyawan dan mendorong karyawan untuk meningkatkan keterampilan (skill), 2) memiliki sistem pelaporan keuangan yang diberkembangkan dengan baik, 3) menjadi fokus pasar (marketfocused) dengan aktif mencari informasi pelanggan dan industri, 4) menjadi peka 
terhadap informasi tentang perubahan di pasar, 5) mempekerjakan dan mempertahankan sejumlah besar orang yang terlatih dalam ilmu pengetahuan, teknik atau matematika, 6) bekerja dalam kemitraan dengan pelanggan internasional, dan 7) mendapatkan informasi dari survei pasar. Lima faktor yang menggambarkan knowledge dissemination: 1) mudah menyebarkan informasi pasar di seluruh organisasi, 2) menyebarluaskan pengetahuan pada pekerjaan, 3) menggunakan teknik (seperti quality circles, case notes, mentoring and coaching untuk menyebarkan pengetahuan), 4) menggunakan teknologi (seperti telekonferensi, konferensi video dan groupware) untuk memfasilitasi komunikasi, dan 5) lebih memilih komunikasi tertulis untuk menyebarkan pengetahuan. Terakhir, responsiveness to knowledge digambarkan oleh tiga faktor berikut: 1) menanggapi atau merespons pengetahuan tentang pelanggan, pesaing dan teknologi, 2) menjadi fleksibel dan oportunistik dengan mudah mengubah produk, proses dan strategi, dan 3) memiliki fungsi pemasaran yang dikembangkan dengan baik (well-developed marketing).

\subsubsection{Knowledge Management System (KMS)}

Selama beberapa dekade konsep manajemen pengetahuan berubah dari seluruh perbandingannya dengan manajemen informasi sampai pada tampilan kontemporer yang memperkuat organisasi pembelajar (organizational learning), interaksi sosial dan penciptaan pengetahuan. Pesatnya perkembangan manajemen pengetahuan adalah salah satu alasan mengapa masih ada perbedaan antara berbagai persepsi tentang apa itu manajemen pengetahuan dan bagaimana organisasi dapat mengelola pengetahuan (Sajeva, 2010). 
Menurut Maier (2007), secara umum, ada kesepakatan tentang perbedaan antara human-oriented (sosial, organisasi, people-centred) dan technology-oriented (teknologi, technology-centred) dalam pendekatan KM. Bibikas (2008) menjelaskan bahwa persepsi yang berbeda dibangun selama diskusi tentang perbedaan perbedaan antara pemanfaatan pengetahuan eksplisit dan tacit: melalui pendekatan technologyoriented, pengetahuan mudah dikodifikasikan dan didokumentasikan, sedangkan pengetahuan yang berada pada pikiran dan keyakinan masyarakat membutuhkan aksi human-oriented.

KMS umumnya dijelaskan dari perspektif teknologi. Grundstein (2008) menekankan, bahwa banyak penulis membatasi pengertian KMS pada gagasan sistem berbasis teknologi informasi yang mengurangi KMS pada sistem pengolahan data. Dari perspektif ini, istilah "knowledge management system" digunakan secara sempit, hanya menitik beratkan pada system informasi dan komunikasi (platform), atau pada produk teknologi tunggal (alat atau teknologi) yang bisa diadopsi dan dirancang untuk mendukung proses KM. Misalnya, Alavi dan Leidner (2001) merujuk KMS untuk kelas sistem informasi yang diterapkan untuk mengelola pengetahuan organisasi. Halhal khas dalam KMS meliputi basis data, intranet, groupware, mesin pencari dan lainlain. Grundstein, (2008) melihat bahwa KMS dapat dibagi menjadi beberapa kategori utama, sebagai berikut: groupware, termasuk e -mail, dan wiki; sistem pendukung keputusan; sistem pakar; sistem manajemen dokumen; jaringan semantik; relasional dan basis data berorientasi objek; alat simulasi; dan kecerdasan buatan.

Menurut sudut pandang ini, KMS memiliki banyak kesamaan dengan sistem informasi dan banyak alat-alat dan teknik KM terkait dengan sistem informasi. Dalam mengidentifikasi perbedaan antara KM tools dan Information Management tools Gallupe (2000) mencatat bahwa KM tools harus mampu menangani kekayaan, konten, 
dan konteks informasi, bukan hanya informasi itu sendiri. Jika tujuan dari sistem informasi adalah penyimpanan yang efektif dan menyediakan informasi sesuai permintaan, target utama dari KMS adalah untuk meningkatkan kualitas pengetahuan spesialis, baik melalui dialog organisasi dengan para ahli yang memiliki pengetahuan atau menterjemahkan informasi di mana pengetahuan yang diperlukan dikodekan (Tuzovsky, Yampolsky, 2003).

Debowski (2006, 141) mempertegas lagi bahwa tujuan KMS adalah menyediakan dukungan teknis untuk memungkinkan penangkapan dan pertukaran pengetahuan secara bebas, mudah dan terbuka di berbagai pemangku kepentingan yang berbeda dalam organisasi. KMS juga menyediakan setiap pengguna dengan saluran untuk memperoleh, mendokumentasikan, mentransfer, membuat dan menerapkan pengetahuan untuk memenuhi prioritas pengetahuan organisasi.

\subsection{Teknologi Informasi dan Komunikasi/TIK (Information Communication \& Technology/ICT)}

Setiap perusahaan membutuhkan informasi internal tentang keadaan keuangan mereka, efektivitas produk mereka, biaya produksi mereka, dan sebagainya, dan mereka membutuhkan informasi eksternal tentang lingkungan di mana pesaing beroperasi, pelanggan, pemasok, dll, yang membantu mereka untuk mengenal pelanggan mereka dan memuaskan mereka dengan secepat dan seefektif mungkin, sehingga mendapatkan keuntungan kompetitif yang berkelanjutan (Maier, 1997).

Saat ini mendapatkan informasi tidak lagi masalah. Kesulitannya terletak dalam memperoleh informasi yang berkualitas, di mana kualitas diukur dalam hal 
akurasi, keandalan, ketepatan (precision), dan ketepatan waktu, dan sejauh mana informasi yang relevan dalam pengambilan keputusan (Huber, 1990).

Revolusi TIK telah memfasilitasi proses mencari dan menemukan informasi, tetapi pada saat yang sama telah menyebabkan pertumbuhan yang penting dalam industri basis data. Perusahaan harus mampu menggunakan TIK untuk memperoleh informasi yang berguna untuk pengambilan keputusan mereka. Banyak perusahaan telah mengembangkan strategi yang mencakup investasi besar-besaran di bidang teknologi informasi dan komunikasi untuk meningkatkan kinerja mereka.

Merujuk pada teori yang dikemukakan Tippins dan Sohi (2003), penelitian ini mendefinisikan kompetensi TIK sebagai bagaimana perusahaan menggunakan teknologi untuk mengelola informasi secara efektif. Sementara TIK adalah istilah dasar umum yang merujuk pada program, komputer, dan telekomunikasi, istilah kompetensi TIK lebih luas dan mengacu pada penggunaan teknologi tersebut untuk memenuhi kebutuhan informasi perusahaan (Gunasekaran, 2001). Penelitian ini membedakan tiga dimensi dalam konsep kompetensi TIK ini, yaitu ICT Knowledge, ICT Operations, dan ICT Infrastructure. Dimensi ini mewakili sumber daya yang menunjukkan kemampuan organisasi untuk memahami dan menggunakan alat (tools) yang diperlukan untuk mengelola informasi tentang pasar dan pelanggan (Tippins dan Sohi, 2003). Selain itu, meskipun ketiga dimensi ini independen, namun harus hadir dalam perusahaan untuk mencapai kompetensi TIK. Misalnya, banyak perusahaan berinvestasi di alat teknis tetapi pada saat yang sama gagal untuk mencapai kompetensi TIK karena mereka tidak memiliki pengetahuan yang diperlukan untuk menggunakan alat tersebut dengan efisien. Penjelasan ke tiga aspek tersebut akan dijelaskan di bawah ini. 


\subsubsection{ICT Knowledge (Pengetahuan TIK)}

Mengingat bahwa pengetahuan adalah "informasi yang dikombinasikan dengan pengalaman, konteks, interpretasi, dan rerefleksi," pengetahuan memiliki komponen tacit yang sulit untuk diukur (Davenport, De Long, dan Beers, 1998, p. 43). Seperti domain tertentu pengetahuan lainnya, pengetahuan TIK dapat dibedakan sebagai bagian dari konsepsi yang lebih umum pengetahuan (Capon and Glazer, 1987). Taylor (1971, p.3) mendefinisikan pengetahuan teknis sebagai "seperangkat prinsip dan teknik yang berguna untuk membawa perubahan ke arah tujuan yang diinginkan." Dalam penelitian ini, pengetahuan TIK dikonseptualisasikan sebagai sejauh mana sebuah perusahaan memiliki organ pengetahuan teknis tentang obyek misalnya sistem berbasis komputer.

\subsubsection{ICT Operations (Operasi TIK)}

Teknis operasional, atau teknik, terdiri dari kegiatan yang dilakukan untuk mencapai tujuan khusus (Mitcham dan Mackey, 1983). Teknis Operasional dapat dianggap sebagai metode, keterampilan, dan proses yang diperlukan untuk menyelesaikan tugas fokal (Granstrand, 1982). Nelson, Peck, dan Kalachek (1967) menunjukkan bahwa teknik terdiri dari proses heterogen, yang sebagian besar diarahkan pada produksi barang dan jasa yang bernilai ekonomis. Konseptualisasi ini sejalan dengan pendapat Capon dan Glazer (1987) dalam ide proses teknologi, yang merupakan seperangkat ide atau langkah-langkah yang digunakan untuk mencapai tujuan (misalnya, produk jadi). Teknis operasional juga dianggap sebagai manifestasi dari pengetahuan teknis (technical knowledge) sehingga pada implementasi 
pengetahuan teknis akan menghasilkan teknis operasional atau keterampilan (skills). Dengan adanya pengetahuan IT yang unggul, keterampilan ini dapat menjadi " $T$ shaped." Artinya, keterampilan tidak hanya mewakili pemahaman yang mendalam tertentu dari "domain pengetahuan," tetapi juga mencerminkan kemampuan untuk mengekspor pengetahuan untuk operasi kongruen lainnya (Leonard-Barton 1995). Pada penelitian ini, operasi TIK dikonseptualisasikan sebagai sejauh mana suatu perusahaan menggunakan TIK untuk mengelola informasi pasar dan pelanggan, meningkatkan efektifitas dan pengambilan keputusan.

\subsubsection{ICT Infrastructure (Infrastruktur TIK)}

Infrastruktur TIK bertindak sebagai enabler, dan peran yang lebih luas adalah pada peningkatan minat dalam dalam produksi dan penyebaran informasi (Reardon, 1996). Infrastruktur TI mengacu pada artefak, alat dan sumber daya yang berkontribusi terhadap akuisisi, pengolahan, penyimpanan, penyebaran dan penggunaan informasi. Menurut definisi ini, infrastruktur IT termasuk elemen seperti perangkat keras, perangkat lunak dan staf pendukung (Lopez, Peon dan Ordas, 2009).

\subsection{Inovasi}

KM muncul sebagai konsep penting dan sering dikutip sebagai faktor pendukung inovasi (Antonelli, 1999; Carneiro, 2000; Dove, 1999; Nonaka \& Takeuchi, 1995). Sementara kebutuhan untuk secara efektif mengelola pengetahuan secara umum diterima, manajemen pengetahuan masih merupakan konsep yang sulit dipahami dan banyak literatur terus mengeksplorasi isu-isu definisi, dan setelah 
sampai definisi diterima secara luas, pengukuran KM dan bagaimana mengidentifikasi pengaruhnya terhadap hasil seperti inovasi dan kinerja perusahaan masih sulit ditentunkan (Darroch dan McNaughton 2002, 5).

KM yang efektif telah disajikan dalam literatur sebagai salah satu metode untuk meningkatkan inovasi dan kinerja. Lebih khusus, penyebaran pengetahuan dan respon terhadap pengetahuan telah diperdebatkan sebagai dua komponen yang akan memiliki dampak paling besar pada penciptaan keunggulan kompetitif yang berkelanjutan, seperti inovasi, karena ambiguitas dan keunikan mereka pada perusahaan (Day, 1994; Fahey dan Prusak, 1998; Grant, 1996; Teece, 1998; Teece, 2000).

Upaya inovatif termasuk pencarian, dan temuan, pengujian, dan pengembangan teknologi baru, produk atau jasa baru, prosedur produksi baru, dan struktur organisasi yang baru. Inovasi adalah tentang melakukan ide (Borghini, 2005). Literatur (Damanpour \& Evan, 1984) menjelaskan inovasi dalam hal sifatnya, sebagai komponen utama, struktur baru atau sistem administrasi, kebijakan, rencana atau program baru, prosedur produksi baru, produk atau jasa baru pada perusahaan, yang telah diperoleh atau dibuat secara internal. Prosedur Inovasi yang berhasil tergantung pada pengetahuan (Gloet \& Terziovski, 2004), khususnya pada pengetahuan tacit (Leonard \& Sensiper, 1998). Pengetahuan yang baru dan bernilai dibuat dan berubah menjadi produk, layanan dan prosedur (Choy, Yew, \& Lin, 2006), dengan mengubah pengetahuan umum ke dalam pengetahuan khusus.

Faktor-faktor skala inovasi yang akan peneliti pakai pada penelitian ini adalah menggunakan skala penelitian Darroch (2005) yang merujuk pada penelitian Booz Allen Hamilton (1982). Inovasi dikategorikan menjadi: baru di dunia (new to the 
world), produk baru untuk perusahaan (new products to the firm), penambahan pada lini produk (additions to existing product lines), perbaikan atau revisi lini produk yang ada (improvements or revisions to existing product lines), pengurangan biaya untuk produk yang sudah ada (cost reductions to existing products), atau reposisi produk yang ada (repositioning of existing products). Baru di dunia (new to the world) adalah karakteristik dari inovasi radikal, selebihnya masuk dalam inovasi inkremental.

Sumber-sumber bacaan tentang hubungan antara KM dan inovasi sudah mulai bermunculan walaupun tidak sebanyak dengan variable lain. Sedighi dan Jalalimanesh (2014) membuat penelitian tentang tren penelitian di bidang KM dan hasilnya dapat dilihat dalam table, sebagai pembanding variable inovasi dan variable popular lainnya.

Tabel 2.2. Top 20 Keywords based on the Publication Year of Articles (sumber: Sedighi \& Jalalimanesh, 2014)

\begin{tabular}{|c|c|c|c|c|c|c|c|c|c|c|c|}
\hline Keywords & 2001 & 2002 & 2003 & 2004 & 2005 & 2006 & 2007 & 2008 & 2009 & 2010 & Total \\
\hline Data mining & 158 & 189 & 268 & 291 & 271 & 359 & 409 & 443 & 546 & 441 & 3375 \\
\hline Risk management & 87 & 110 & 140 & 142 & 154 & 207 & 212 & 215 & 118 & 323 & 1708 \\
\hline Social capital & 56 & 67 & 100 & 97 & 136 & 151 & 193 & 232 & 263 & 241 & 1536 \\
\hline $\begin{array}{l}\text { Organizational } \\
\text { culture }\end{array}$ & 13 & 18 & 47 & 32 & 37 & 56 & 70 & 79 & 92 & 98 & 542 \\
\hline Expert system & 22 & 41 & 64 & 47 & 47 & 54 & 68 & 74 & 63 & 57 & 537 \\
\hline $\begin{array}{l}\text { Organizational } \\
\text { learning }\end{array}$ & 38 & 38 & 42 & 37 & 36 & 50 & 38 & 45 & 63 & 58 & 445 \\
\hline Risk assessment & 23 & 29 & 44 & 43 & 34 & 48 & 36 & 50 & 15 & 59 & 381 \\
\hline Clustering & 8 & 22 & 30 & 37 & 51 & 35 & 51 & 58 & 44 & 44 & 380 \\
\hline Machine learning & 27 & 25 & 41 & 38 & 41 & 51 & 34 & 42 & 36 & 45 & 380 \\
\hline Knowledge & 22 & 23 & 30 & 33 & 23 & 37 & 42 & 53 & 52 & 40 & 355 \\
\hline Knowledge sharing & 7 & 9 & 13 & 18 & 25 & 26 & 38 & 70 & 78 & 71 & 355 \\
\hline $\begin{array}{l}\text { Knowledge } \\
\text { acquisition }\end{array}$ & 31 & 33 & 34 & 27 & 18 & 43 & 38 & 41 & 39 & 36 & 340 \\
\hline Ontology & 9 & 9 & 24 & 24 & 25 & 34 & 39 & 50 & 62 & 55 & 331 \\
\hline Education & 16 & 18 & 21 & 19 & 26 & 30 & 36 & 50 & 60 & 47 & 323 \\
\hline
\end{tabular}


Kebutuhan untuk mengidentifikasi berbagai jenis inovasi dalam penelitian harus jelas karena setiap jenis inovasi mungkin membutuhkan sumber daya dan kompetensi inti yang berbeda untuk melihat pengaruhnya.

Inovasi secara umum diterima sebagai pengembangan dan implementasi ideide baru (Van de Ven, 1986). Sebagaimana telah disinggung di atas, terdapat banyak sekali bentuk-bentuk inovasi, misalnya, inovasi dapat terjadi pada berbagai tingkat dalam suatu organisasi: pada produk (apa yang diproduksi), proses (bagaimana diproduksi) dan bentuk organisasi (di mana diproduksi) (Chandrashekaran, Mehta, Chandrashekaran dan Grewal, 1999). Darroch (2005) pada akhirnya membagi kisaran (range) inovasi dari radikal (radical) sampai incremental (incremental).

Perbedaan antara inovasi inkremental dan radikal penting mengingat efek yang berbeda dari setiap jenis inovasi. Kebanyakan inovasi adalah incremental, artinya menampilkan dirinya sebagai ekstensi atau modifikasi dari produk yang sudah ada (Dosi, 1988). Ide-ide untuk inovasi ini cenderung datang dari pasar, sehingga akan didasarkan pada riset pasar antara pelanggan saat ini dan calon pelanggan, juga bisa dimungkinkan juga dari informasi tentang pesaing dan tren industri. Oleh karena itu inovasi inkremental biasanya diklasifikasikan sebagai market-pull innovations. Lebih lanjut, inovasi ini umumnya cenderung muncul dari perusahaan yang dikategorikan sebagai market-oriented karena perusahaan-perusahaan ini disebut lebih mahir dalam mengumpulkan, menyebarkan dan merespon informasi intelejen tentang pasar (Kohli dan Jaworksi, 1990). Karena inovasi inkremental tidak memerlukan perubahan yang signifikan dari praktek bisnis yang ada, inovasi inkremental cenderung untuk meningkatkan kompetensi internal yang telah ada dengan memberikan kesempatan bagi mereka dalam organisasi untuk membangun know-how yang sudah ada (Tushman dan Anderson, 1986). 
Sebaliknya inovasi radikal cenderung menjadi kompetensi yang merubah total, sering membuat keterampilan dan pengetahuan yang sudah ada mubazir (Tushman dan Anderson, 1986). Selain itu, inovasi radikal seringkali memerlukan praktek manajemen yang berbeda (O'Connor, 1998; Rice, O'Connor, Peters dan Morone, 1998). Inovasi ini lebih mungkin berasal dari para ilmuwan dan sebagainya diklasifikasikan sebagai technology-push innovations (Dosi, 1988; Workman Jr, 1993; Green, Gavin and Aiman-Smith, 1995; O'Connor, 1998). Inovasi radikal sering menempatkan bisnis beresiko, karena akan lebih sulit berhasil dalam komersialisasi. Namun, inovasi radikal dianggap penting untuk keberhasilan jangka panjang karena melibatkan pengembangan dan penerapan teknologi baru, beberapa di antaranya mungkin mengubah struktur pasar yang ada (Veryzer Jr, 1998).

Sebuah inovasi inkremental, menurut definisi, akan lebih diselaraskan dengan kebutuhan sebagaimana diungkapkan konsumen. Inovasi radikal cenderung mengabaikan pernyataan kebutuhan konsumen. Hal ini sering dikutip sebagai alasan yang mungkin mengapa inovasi radikal gagal (Gatignon dan Robertson, 1985).

Faktor pertama menyumbang inovasi inkremental menurut Darroch (2002) termasuk penambahan produk atau jasa baru untuk rentang produk yang ada dan revisi dan reposisi produk atau jasa yang sudah ada. Faktor kedua diberi label "inovasi yang mengubah perilaku konsumen" dan memberikan sesuatu yang baru dalam dunia inovasi. Item yang termasuk dalam faktor ini mencakup peluncuran produk dan jasa baru bersama dengan peluncuran produk atau jasa yang menawarkan konsumen keuntungan atau manfaat yang lebih besar atas produk yang ada dan juga membutuhkan konsumen untuk mengubah perilaku mereka. Faktor terakhir meliputi keduanya; benar-benar produk/jasa yang baru dan baru untuk inovasi perusahaan yang 
memiliki potensi untuk menghancurkan kompetensi yang ada karena perusahaan tidak memiliki pengalaman teknologi dan bisnis.

\subsection{Industri Kreatif}

Definisi Industri Kreatif yang saat ini banyak digunakan oleh pihak yang berkecimpung dalam industri kreatif, adalah definisi berdasarkan UK DCMS Task Force 1998: "creative industries as those industries which have their origin in individual creativity, skill and talent, and which have a potential for wealth and job creation through the generation and exploitation of intellectual property and content".

Definisi idustri kratif sendiri menurut Departemen Perdagangan pada studi pemetaan industri kreatif tahun 2007 dalam buku Pengembangan Ekonomi Kreatif Indonesia 2025 (2008) adalah: "Industri yang berasal dari pemanfaatan kreativitas, keterampilan, serta bakat individu untuk menciptakan kesejahteraan serta lapangan pekerjaan melalui penciptaan dan pemanfaatan daya kreasi dan daya cipta individu tersebut.”

Industri kreatif dapat dikelompokkan ke dalam empat belas subsektor (Departemen Perdagangan RI, 2008, pp.7), yaitu Periklanan, Penerbitan dan Percetakan, TV dan Radio, Video dan Fotografi, Musik, Seni Pertunjukan, Arsitektur, Desain, Fesyen, Kerajinan, Pasar Barang Seni, Permainan Interaktif, Layanan Komputer dan Piranti Lunak, Penelitian dan Pengembangan. Penjelasan masingmasing subsektor dijabarkan dibawah ini.

Periklanan adalah kegiatan kreatif yang berkaitan jasa periklanan (komunikasi satu arah dengan menggunakan medium tertentu), yang meliputi proses kreasi, 
produksi dan distribusi dari iklan yang dihasilkan, misalnya: perencanaan komunikasi iklan, iklan luar ruang, produksi material iklan, promosi, kampanye relasi publik, tampilan iklan di media cetak (surat kabar, majalah) dan elektronik (televisi dan radio), pemasangan berbagai poster dan gambar, penyebaran selebaran, pamflet, edaran, brosur dan reklame sejenis, distribusi dan delivery advertising materials atau samples, serta penyewaan kolom untuk iklan.

Arsitektur adalah kegiatan kreatif yang berkaitan dengan jasa desain bangunan, perencanaan biaya konstruksi, konservasi bangunan warisan, pengawasan konstruksi baik secara menyeluruh dari level makro (Town planning, urban design, landscape architecture) sampai dengan level mikro (detail konstruksi, misalnya: arsitektur taman dan desain interior).

Pasar Barang Seni yaitu kegiatan kreatif yang berkaitan dengan perdagangan barang-barang asli, unik dan langka serta memiliki nilai estetika seni yang tinggi melalui lelang, galeri, toko, pasar swalayan, dan internet, meliputi barang-barang musik, percetakan, kerajinan, automobile, film, seni rupa dan lukisan.

Kerajinan yaitu kegiatan kreatif yang berkaitan dengan kreasi, produksi dan distribusi produk yang dibuat dan dihasilkan oleh tenaga pengrajin yang berawal dari desain awal sampai dengan proses penyelesaian produknya, antara lain meliputi barang kerajinan yang terbuat dari: batu berharga, serat alam maupun buatan, kulit, rotan, bambu, kayu, logam (emas, perak, tembaga, perunggu, besi) kayu, kaca, porselin, kain, marmer, tanah liat, dan kapur. Produk kerajinan pada umumnya hanya diproduksi dalam jumlah yang relatif kecil (bukan produksi masal). 
Desain yaitu kegiatan kreatif yang terkait dengan kreasi desain grafis, desain interior, desain produk, desain industri, konsultasi identitas perusahaan dan jasa riset pemasaran serta produksi kemasan dan jasa pengepakan.

Fesyen yaitu kegiatan kreatif yang terkait dengan kreasi desain pakaian, desain alas kaki, dan desain aksesoris mode lainnya, produksi pakaian mode dan aksesorisnya, konsultansi lini produk fesyen, serta distribusi produk fesyen.

Video, Film dan Fotografi adalah kegiatan kreatif yang terkait dengan kreasi, produksi video, film, dan jasa fotografi, serta distribusi rekaman video, film dan hasil fotografi. Termasuk di dalamnya penulisan skrip, dubbing film, sinematografi, sinetron, dan eksibisi film.

Permainan Interaktif yaitu kegiatan kreatif yang berkaitan dengan kreasi, produksi, dan distribusi permainan komputer dan video yang bersifat hiburan, ketangkasan, dan edukasi. Subsektor permainan interaktif bukan didominasi sebagai hiburan semata-mata tetapi juga sebagai alat bantu pembelajaran atau edukasi.

Musik yaitu kegiatan kreatif yang berkaitan dengan kreasi/komposisi, pertunjukan musik, reproduksi, dan distribusi dari rekaman suara.

Seni Pertunjukan adalah kegiatan kreatif yang berkaitan dengan usaha yang berkaitan dengan pengembangan konten, produksi pertunjukan, pertunjukan balet, tarian tradisional, tarian kontemporer, drama, musik-tradisional, musik-teater, opera, termasuk tur musik etnik, desain dan pembuatan busana pertunjukan, tata panggung, dan tata pencahayaan.

Penerbitan dan Percetakan yaitu kegiatan kreatif yang terkait dengan penulisan konten dan penerbitan buku, jurnal, koran, majalah, tabloid, dan konten digital serta 
kegiatan kantor berita dan pencari berita. Subsektor ini juga mencakup penerbitan perangko, meterai, uang kertas, blanko check, giro, surat andil, obligasi surat saham, surat berharga lainnya, passport, tiker pesawat terbang, dan terbitan khusus lainnya. Juga mencakup penerbitan foto-foto, grafir (engraving) dan kartu pos, formulir, poster, reproduksi, percetakan lukisan, dan barang cetakan lainnya, termasuk rekaman mikro film.

Layanan Komputer dan Piranti Lunak yaitu kegiatan kreatif yang terkait dengan pengembangan teknologi informasi termasuk jasa layanan komputer, pengolahan data, pengembangan database, pengembangan piranti lunak, integrasi sistem, desain dan analisis sistem, desain arsitektur piranti lunak, desain prasarana piranti lunak dan piranti keras, serta desain portal termasuk perawatannya.

Televisi dan Radio yaitu kegiatan kreatif yang berkaitan dengan usaha kreasi, produksi dan pengemasan acara televise (seperti games, kuis, reality show, infotainment, dan lainnya), penyiaran, dan transmisi konten acara televise dan radio, termasuk kegiatan station relay (pemancaran kembali) siaran radio dan televisi.

Riset dan Pengembangan yaitu kegiatan kreatif yang terkait dengan usaha inovatif yang menawarkan penemuan ilmu dan teknologi dan penerapan ilmu dan pengetahuan tersebut untuk perbaikan produk dan kreasi produk baru, proses baru, material baru, alat baru, metode baru, dan teknologi baru yang dapat memenuhi kebutahan pasar; termasuk yang berkaitan dengan humaniora seperti penelitian dan pengembangan bahasa, sastra, dan seni; serta jasa konsultasi bisnis dan manajemen. 


\subsection{Structural Equation Modeling (SEM)}

Structural Equation Modeling (SEM) adalah gabungan analisis faktor dan regresi berganda yang melibatkan banyak variabel (Santoso, 2014 p.1). Pada tahun 1950-an, SEM sudah mulai dikemukakan oleh para ahli statistik yang mencari metode untuk membuat model yang dapat menjelaskan hubungan di antara variabelvariabel. Persoalan timbul karena banyak variabel yang termasuk variabel laten yang menimbulkan kesulitan tersendiri dalam pengukurannya.

Demikian juga dalam penelitian ini; variabel Teknologi Informasi dan Komunikasi, Knowledge Management dan Inovasi tidak dapat begitu saja diukur dengan alat ukur, karena merupakan susuatu yang kompleks, dan harus diukur dengan beberapa indikator (variabel manifest). Variabel laten adalah variabel yang mengharuskan adanya sejumlah variabel manifest atau indikator agar variabel laten tersebut dapat diukur. Tanpa sejumlah indikator maka variabel laten tidak dapat diukur begitu saja.

Dalam sebuah model SEM, sebuah variabel laten dapat berfungsi sebagai variabel eksogen dan endogen. Variabel eksogen adalah variabel independen yang mempengaruhi variabel dependen. Pada model SEM, variabel eksogen ditunjukkan dengan adanya anak panah yang berasal dari variabel tersebut menuju variabel endogen. Variabel endogen adalah variabel dependen yang dipengaruhi oleh variabel independen (eksogen). Pada model SEM, variabel endogen ditunjukkan dengan anak panah yang menuju ke variabel tersebut.

Santoso (2014) mengemukakan empat tahapan penggunaan SEM dalam kegiatan penelitian, yaitu membuat sebuah model SEM (Model Specification), 
menyiapkan desain penelitian dan pengumpulan data, model identification dan menguji model (model testing dan model estimation).

Proses SEM tentu tidak bisa dilakukan secara manual, selain karena keterbatasan kemampuan manusia, juga karena kompelsitas model dan alat statistik yang digunakan. Kemajuan teknologi informasi, khususnya dalam pembuatan software, telah mendorong munculnya software khusus untuk perhitungan alat statistik dasar dari SEM, yakni analisis faktor dan analisis regresi berganda; seperti LISREL, AMOS, EQS, dan Mplus.

\subsection{AMOS (Analysis of Moment Structure)}

Amos merupakan kependekan dari Analisis of Moment Structures yang digunakan sebagai pendekatan umum analisis data dalam Model Persamaan Struktural (Structural Equation Model) atau yang dikenal dengan SEM. SEM dikenal juga sebagai Analysis of Covariance Structures atau disebut juga model sebab akibat (causal modeling). Dengan menggunakan Amos maka perhitungan rumit dalam SEM akan jauh lebih mudah dilakukan dibandingkan dengan menggunakan perangkat lunak lainnya. Lebih lagi penggunaan Amos akan mempercepat dalam membuat spesifikasi, melihat serta melakukan modifikasi model secara grafik dengan menggunakan tool yang sederhana.

Metode-metode analisis dalam Amos yang ada saat ini diantranya ialah: Maximum Likelihood, Unweighted Least Square, Generalized Least Square, Browne's Asymptotically Distribution-Free Criterion, dan Scale Free Least Square. 


\subsection{Tinjauan Penelitian Terdahulu}

Tabel 2.3. Tinjauan Penelitian Terdahulu

\begin{tabular}{|c|c|c|c|c|c|}
\hline No & Peneliti & Judul & Variabel & $\begin{array}{c}\text { Bentuk } \\
\text { Penelitian }\end{array}$ & Hasil Penelitian \\
\hline 1 & $\begin{array}{l}\text { Susana Pérez } \\
\text { López, José } \\
\text { Manuel Montes } \\
\text { Peón, dan } \\
\text { Camilo José } \\
\text { Vázquez Ordás } \\
\text { (2009) }\end{array}$ & $\begin{array}{l}\text { Information Technology } \\
\text { as an Enabler of } \\
\text { Knowledge } \\
\text { Management: An } \\
\text { Empirical Analysis }\end{array}$ & $\begin{array}{l}\text { Information } \\
\text { Technology, } \\
\text { Knowledge } \\
\text { Management }\end{array}$ & Research & $\begin{array}{l}\text { IT has a positive impact on } \\
\text { knowledge management, } \\
\text { The findings of the research } \\
\text { also have important } \\
\text { implications for managers. } \\
\text { Managers should not only } \\
\text { focus on allocating sufficient } \\
\text { resources for IT investments. }\end{array}$ \\
\hline 2 & $\begin{array}{l}\text { Walter Omona, } \\
\text { Theo van der } \\
\text { Weide, Jude } \\
\text { Lubega } \\
\text { (2010) }\end{array}$ & $\begin{array}{l}\text { Using ICT to enhance } \\
\text { Knowledge } \\
\text { Management in higher } \\
\text { education: A conceptual } \\
\text { framework and } \\
\text { research agenda }\end{array}$ & $\begin{array}{l}\text { ICT, } \\
\text { Knowledge } \\
\text { Management }\end{array}$ & Research & $\begin{array}{l}\text { This paper proposed a } \\
\text { conceptual framework for } \\
\text { using ICT to enhance KM in } \\
\text { higher education } \\
\text { The framework highlights the } \\
\text { relationships and interplay } \\
\text { between higher education } \\
\text { process, KM enabling ICT, } \\
\text { KM processes, and KM } \\
\text { outcomes as constituting the } \\
\text { key elements of the } \\
\text { framework }\end{array}$ \\
\hline 3 & $\begin{array}{l}\text { Sayyed Mohsen } \\
\text { Allameh, Saba } \\
\text { Khadem Abbas } \\
\text { (2010) }\end{array}$ & $\begin{array}{l}\text { The Relationship } \\
\text { Between Knowledge } \\
\text { Management Practices } \\
\text { And Innovation Level In } \\
\text { Organizations: Case } \\
\text { Study Of Sub- } \\
\text { Companies Of Selected } \\
\text { Corporations In The } \\
\text { City Of Esfahan }\end{array}$ & $\begin{array}{l}\text { Knowledge } \\
\text { Management } \\
\text { Practices, } \\
\text { Innovation } \\
\text { Level }\end{array}$ & $\begin{array}{l}\text { Case Study } \\
\text { Locus : } \\
\text { Esfahan }\end{array}$ & $\begin{array}{l}\text { correlation coefficients } \\
\text { between the three knowledge } \\
\text { management practices which } \\
\text { are significant with } 99 \% \\
\text { confidence. } \\
\text { "There is a strong, positive } \\
\text { and significant relationship } \\
\text { between knowledge } \\
\text { management practices with } \\
\text { each other." }\end{array}$ \\
\hline 4 & $\begin{array}{l}\text { Jenny Darroch } \\
\text { (2005) }\end{array}$ & $\begin{array}{l}\text { Knowledge } \\
\text { management, } \\
\text { innovation and firm } \\
\text { performance }\end{array}$ & $\begin{array}{l}\text { Knowledge } \\
\text { management, } \\
\text { innovation, } \\
\text { firm } \\
\text { performance }\end{array}$ & Research & $\begin{array}{l}\text { All three knowledge } \\
\text { management components } \\
\text { were found to have a direct } \\
\text { effect on innovation, but only } \\
\text { responsiveness to knowledge } \\
\text { directly contributed to } \\
\text { financial performance }\end{array}$ \\
\hline 5 & $\begin{array}{l}\text { Jenny Darroch, } \\
\text { Rod } \\
\text { McNaughton } \\
\text { (2002) }\end{array}$ & $\begin{array}{l}\text { Examining the link } \\
\text { between knowledge } \\
\text { management practices } \\
\text { and types of innovation }\end{array}$ & $\begin{array}{l}\text { knowledge } \\
\text { management } \\
\text { practices, } \\
\text { innovation }\end{array}$ & Research & $\begin{array}{l}\text { Incremental innovations did } \\
\text { not come from firms that } \\
\text { responded to knowledge } \\
\text { about the market or had an } \\
\text { effective marketing function } \\
\text { but from firms that were } \\
\text { sensitive to information about } \\
\text { changes in the marketplace } \\
\text { and responded to knowledge } \\
\text { about technology. } \\
\text { Radical innovations were }\end{array}$ \\
\hline
\end{tabular}




\begin{tabular}{|l|l|l|l|}
\hline & & & $\begin{array}{l}\text { expected to come from firms } \\
\text { with a technological } \\
\text { orientation. }\end{array}$ \\
& & & $\begin{array}{l}\text { All innovations required } \\
\text { flexible and opportunistic } \\
\text { organisations. }\end{array}$ \\
\hline
\end{tabular}




\section{BAB III METODE PENELITIAN}

Pada Bab III ini akan dibahas secara detail metode yang akan digunakan untuk menjawab sub bab Perumusan Masalah sebagaimana telah dijelaskan pada Bab I berdasarkan kajian teori-teori yang mendukung pada Bab II. Pembahasan terutama akan mengkaji kerangka pikir, model penelitian, variabel-variabel yang dipakai dalam penelitian ini, hipotesis yang dibangun, populasi dan sampel, metode pengumpulan data, validitas dan reabilitas dan metode analisis.

\subsection{Kerangka Pikir}

Dalam penelitian kuantitatif, masalah yang dibawa oleh peneliti harus sudah jelas, dan ditunjukkan dengan data yang valid. Setelah masalah diidentifikasikan, dan dibatasi, maka selanjutnya masalah tersebut dirumuskan. Rumusan masalah pada umumnya dinyatakan dalam kalimat pertanyaan. Dengan pertanyaan ini maka akan dapat memandu peneliti untuk kegiatan penelitian. Berdasarkan rumusan masalah tersebut, maka peneliti menggunakan berbagai teori untuk memperjelas masalah dan menjawabnya.

Dalam penelitian ini, yaitu sebuah model persamaan struktural atau Structural Equation Modeling, langkah pertama adalah mengkaji berbagai teori dan literatur yang merupakan temuan-temuan terdahulu yang relevan. Dari kajian dan sintetis teori serta temuan-temuan sebelumnya lalu disusunlah model persamaan struktural. Langkah ini disebut membuat spesifikasi model persamaan struktural (Haryono dan Wardoyo, 2012:8). 
Teori diwujudkan dalam bentuk hipotesis atau dugaan sementara. Jika hipotesis telah dirumuskan, proses penelitian dilanjutkan ke proses observasi atau pengumpulan data. Data yang telah dikumpulkan kemudian dianalisis untuk memperoleh kesimpulan yang dapat digeneralisasikan. Dari hasil penelitian yang telah digeneralisasikan tersebut dapat diposisikan sebagai teori.

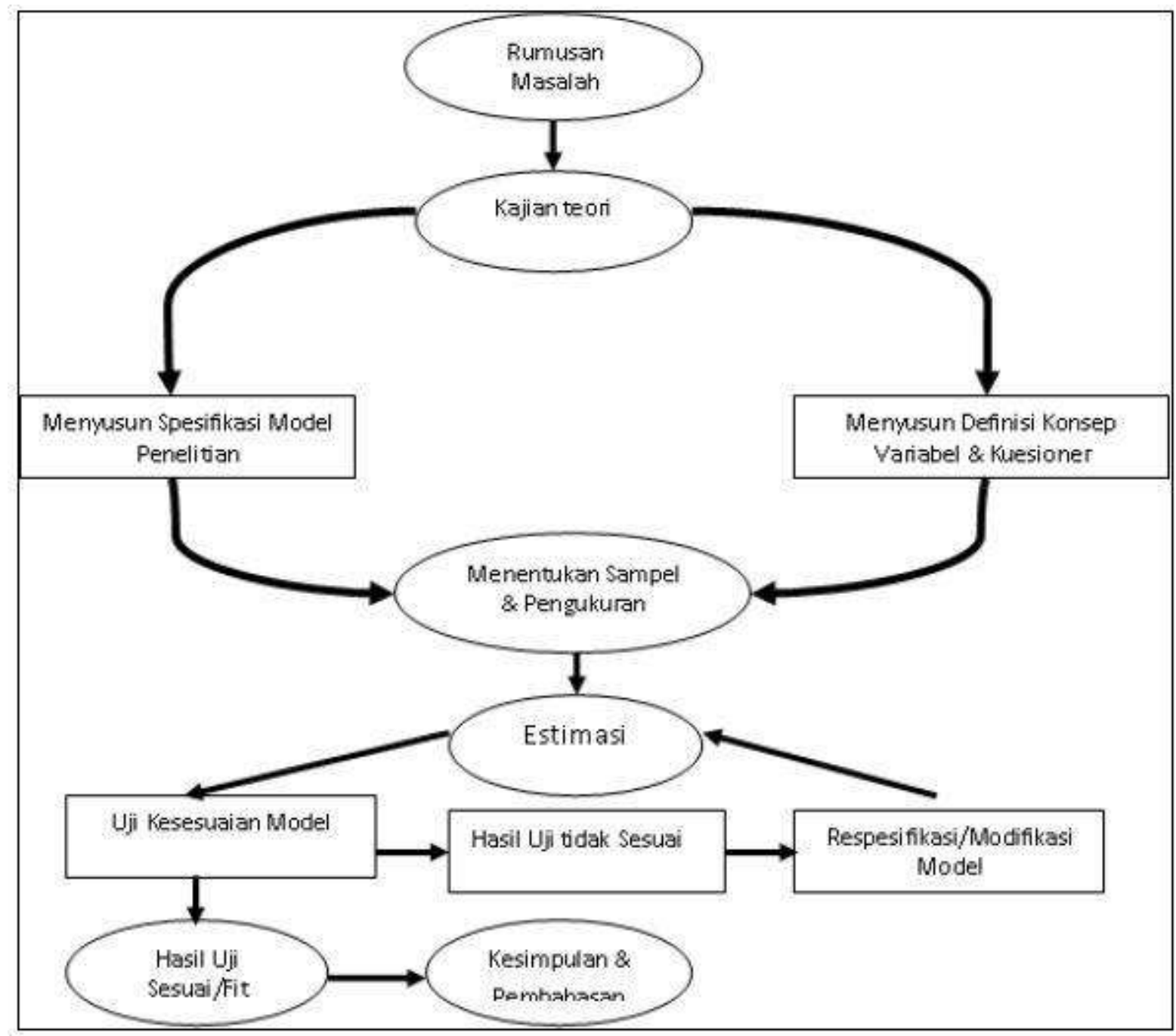

Gambar 3.1. Kerangka Pikir Penelitian

Sumber: Haryono dan Wardoyo (2010:8)

\subsection{Model Penelitian}


Model Penelitian merupakan sintesa tentang hubungan antara variabel yang disusun dari berbagai teori yang telah dideskripsikan pada Bab II. Selanjutnya dianalisis secara kritis dan sistematis, sehingga menghasilkan sintesa tentang hubungan antara variabel penelitian.

Pada variabel Kompetensi Teknologi Informasi (TIK) terdiri dari tiga yaitu Pengetahuan TIK (ICT Knowledge), Operasi TIK (ICT Operations), dan Infrasutruktur TIK (ICT Infrastructure), sedangkan variabel KM yaitu knowledge process terdiri dari knowledge generation, knowledge transfer dan knowledge codification and storage, yang terakhir adalah variabel inovasi. Sintesa tentang hubungan variabel tersebut, selanjutnya digunakan untuk merumuskan hipotesis yang akan dibahas kemudian.

Sesuai dengan hakikat tujuan penelitian ini, yaitu hubungan antara variabel terikat (dependent variable), variabel intervening dengan variabel bebas (independent variable), maka kerangka penelitian secara sederhana dapat digambarkan sebagai berikut:

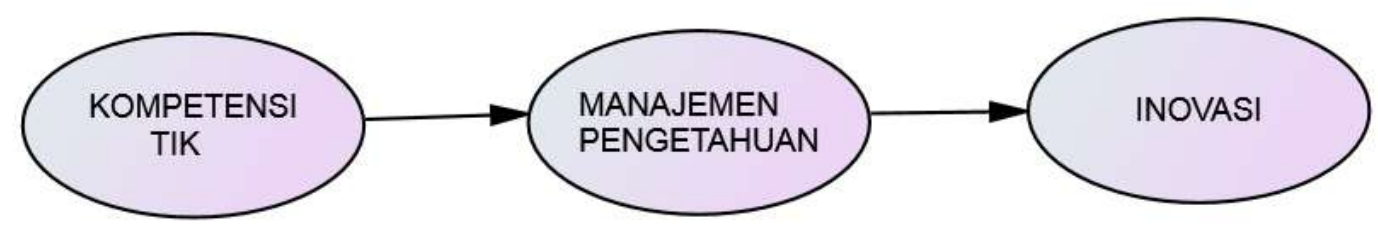

Gambar 3.2. Model penelitian 


\subsection{Variabel}

Berdasarkan studi literatur dan kajian mendalam penelitian-penelitan sebelumnya, maka peneliti membagi variabel penelitian ini ke dalam variabel independen, variabel intervening, dan variabel dependen.

Menurut Sugiyono (2013:38), variabel adalah konstruk (constructs) atau sifat yang akan dipelajari. Di bagian ini Sugiyono menyatakan bahwa variabel dapat dikatakan sebagai suatu sifat yang diambil dari suatu nilai yang berbeda (different values).

Secara umum peneliti mengemukakan dua variabel yang akan diteliti, adapun variabel yang akan diteliti di dalam penelitian ini adalah variabel Laten dan variabel Manifes. Variabel Laten dan variabel Manifest adalah konsep penting dalam Structural Equation Modeling. Menurut Hair dalam (Yamin dan Kurniawan, 2009:6) Variabel Laten adalah operasionalisasi suatu konstruk dalam model persamaan struktural, sebuah konstruk laten tidak dapat diukur secara langsung tetapi dapat dipresentasikan atau ditentukan oleh satu atau lebih variabel (indikator), sedangkan Variabel manifest adalah nilai observasi untuk bagian spesifik yang dipertanyakan, baik dari responden yang menjawab pertanyaan misalnya kuesioner maupun observasi yang dilakukan oleh peneliti. 


\subsubsection{Variabel Penelitian}

Variabel pada dasarnya adalah segala sesuatu yang dapat diberi berbagai macam nilai (Indriantoro dan Supomo, 2002). Variabel yang menghubungkan variabel satu dengan variabel lainnya dalam penelitian ini dapat dibedakan sebagai berikut :

1. Variabel Independen : Berikut ini adalah variabel independen dalam penelitian ini: Kompetensi Teknologi Informasi dan Komunikasi (TIK). Dalam model SEM, variabel ini disebut variabel eksogen.

2. Variabel Intervening : Berikut ini adalah variabel intervening dalam penelitian ini: Manajemen Pengetahuan (knowledge management). Dalam model SEM, variabel ini termasuk dalam variabel endogen.

3. Variabel Dependen: variabel dependen pada penelitian ini adalah Inovasi. Dalam SEM, variabel ini disebut variabel endogen.

\subsubsection{Operasional Variabel}

Operasional variabel merupakan penjelasan dari bagian-bagian variabel yang terdiri dari subvariabel, indikator yang menggunakan jenis ukuran tertentu. Operasionalisasi menggunakan skala tertentu yang disesuaikan dengan tujuan penelitian. Berikut ini ialah operasionalisasi variabel yang diteliti:

Tabel 3.1. Operasi Varabel

\begin{tabular}{|l|l|l|l|l|l|}
\hline \multicolumn{1}{|c|}{ Variabel } & \multicolumn{1}{|c|}{$\begin{array}{c}\text { Konsep } \\
\text { Variabel }\end{array}$} & \multicolumn{1}{|c|}{ Dimensi } & Indikator & $\begin{array}{c}\text { Skala } \\
\text { Pengukuran }\end{array}$ & $\begin{array}{c}\text { Skala } \\
\text { Pengujian }\end{array}$ \\
\hline $\begin{array}{l}\text { ICT } \\
\text { Competency }\end{array}$ & $\begin{array}{l}\text { ICT } \\
\text { Competency } \\
\text { lebih luas dan } \\
\text { mengacu pada }\end{array}$ & ICT & $\begin{array}{l}\text { Knowledge } \\
\text { Staf technical support IT } \\
\text { memiliki pengetahuan } \\
\text { yang cukup untuk } \\
\text { menangani sistem }\end{array}$ & Interval & Likert \\
\hline
\end{tabular}




\begin{tabular}{|c|c|c|c|c|c|}
\hline \multirow[b]{4}{*}{$\begin{array}{l}\text { Knowled } \\
\text { Manager } \\
\text { Process }\end{array}$} & \multirow[t]{3}{*}{$\begin{array}{l}\text { penggunaan } \\
\text { teknologi } \\
\text { tersebut untuk } \\
\text { memenuhi } \\
\text { kebutuhan } \\
\text { informasi } \\
\text { perusahaan } \\
\text { (Gunasekaran } \\
\text {, 2001). }\end{array}$} & & $\begin{array}{l}\text { berbasis komputer } \\
\text { - Memiliki keahlian teknis } \\
\text { berbasis komputer yang } \\
\text { tinggi } \\
\text { - Memahami } \\
\text { (berpengetahuan) } \\
\text { tentang inovasi baru } \\
\text { bidang komputer }\end{array}$ & & \\
\hline & & $\begin{array}{l}\text { ICT } \\
\text { Operations }\end{array}$ & 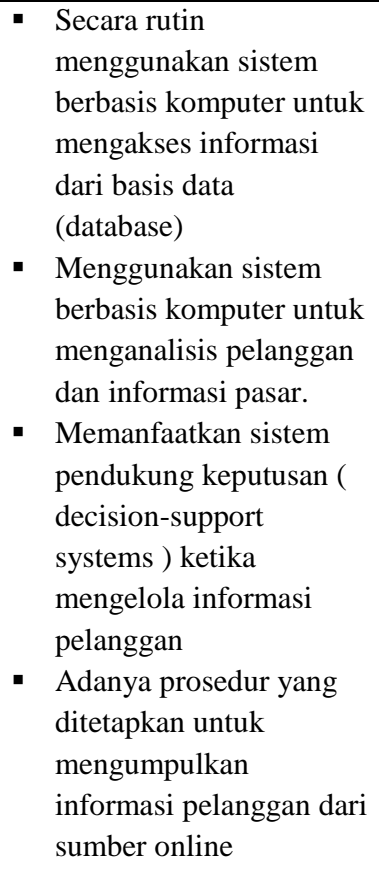 & Interval & Likert \\
\hline & & $\begin{array}{l}\text { ICT } \\
\text { Infrastructure }\end{array}$ & $\begin{array}{l}\text { - Memiliki departemen } \\
\text { Manajemen Sistem } \\
\text { Informasi resmi dalam } \\
\text { struktur Organisasi } \\
\text { - Mempekerjakan seorang } \\
\text { manajer yang bertugas } \\
\text { utama meliputi } \\
\text { pengelolaan teknologi } \\
\text { informasi } \\
\text { - Peralatan TIK di } \\
\text { perusahaan terhubungan } \\
\text { dalam jaringan } \\
\text { komputer/internet } \\
\text { - Adanya software aplikasi } \\
\text { yang fleksibel yang dapat } \\
\text { disesuaikan sesuai } \\
\text { kebutuhan }\end{array}$ & Interval & Likert \\
\hline & $\begin{array}{l}\text { KM dapat } \\
\text { dirangkum ke } \\
\text { dalam tiga } \\
\text { proses utama, } \\
\text { sebagaimana } \\
\text { digunakan } \\
\text { oleh Lopez, } \\
\text { Peon, Ordas } \\
\text { (2009) dalam }\end{array}$ & $\begin{array}{l}\text { Knowledge } \\
\text { Generation }\end{array}$ & $\begin{array}{l}\text { Secara teratur bertemu } \\
\text { dengan pelanggan kami } \\
\text { untuk mencari tahu apa } \\
\text { kebutuhan/harapan } \\
\text { mereka } \\
\text { - Memiliki hubungan } \\
\text { dengan para professional } \\
\text { dan praktisi } \\
\text { - Memiliki system yang }\end{array}$ & Interval & Likert \\
\hline
\end{tabular}




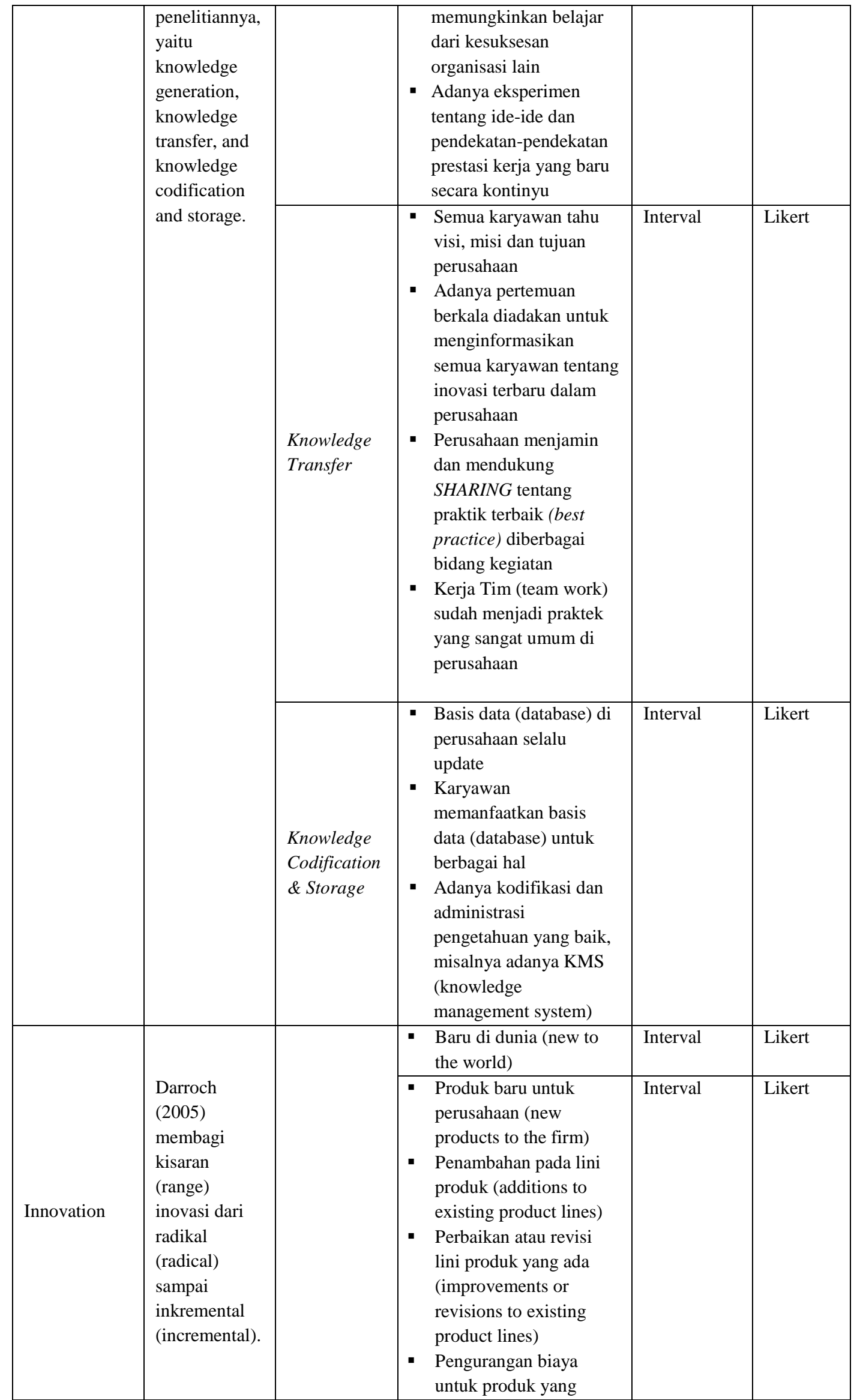




\begin{tabular}{|l|l|l|l|l|}
\hline & & $\begin{array}{l}\text { sudah ada (cost } \\
\text { reductions to existing } \\
\text { products), } \\
\text { Reposisi produk yang } \\
\text { ada (repositioning of } \\
\text { existing products). }\end{array}$ & & \\
\hline
\end{tabular}

\subsection{Hipotesis}

Semula istilah hipotesis berasalah dari bahasa Yunani yang mempunyai dua kata "hupo" (sementara) dan "thesis" (pernyataan atau teori). Karena hipotesis merupakan pernyataan sementara yang masih lemah kebenarannya, maka perlu diuji kebenarannya. Kemudian para ahli menafsirkan arti hipotesis adalah dugaan terhadap hubungan antara dua variabel atau lebih. Atas dasar definisi di atas, dapat diartikan bahwa hipotesis adalah jawaban atau dugaan sementara yang harus diuji kebenarannya (Siregar, 2013, p.38).

Berdasarkan hubungan antar variabel sebagaimana digambarkan dalam kerangka pikir, berikut ini rumusan hipotesis yang akan dibahas dalam penelitian ini:

H1: Kompetensi Teknologi Informasi dan Komunikasi (TIK) memiliki pengaruh positif terhadap proses Manajemen Pengetahuan (knowledge management)

H2a: Manajemen Pengetahuan memiliki pengaruh positif terhadap Inovasi

H2b: Manajemen Pengetahuan memediasi hubungan Kompetensi TIK dan Inovasi 


\subsection{Populasi dan Sampel}

Populasi dan sampel diperlukan dalam sebuah penelitian untuk mengumpulkan data dari variabel yang diteliti. Populasi adalah wilayah generalisasi yang terdiri atas: obyek/subyek yang mempunyai kualitas dan karakteristik tertentu yang ditetapkan oleh peneliti untuk dipelajari dan kemudian ditarik kesimpulan (Sugiyono, 1999).

\subsubsection{Populasi}

Populasi dalam penelitian ini adalah pelaku industri kreatif di kota Batam. Dari empat belas subsektor indutri kreatif, yaitu Periklanan, Penerbitan dan Percetakan, TV dan Radio, Video dan Fotografi, Musik, Seni Pertunjukan, Arsitektur, Desain, Fesyen, Kerajinan, Pasar Barang Seni, Permainan Interaktif, Layanan Komputer dan Piranti Lunak, Penelitian dan Pengembangan (Departemen Perdagangan RI, 2008, pp.7), oleh keterbatasan waktu dan tenaga, dalam penelitian ini dibatasi hanya lima subsektor, yaitu :

1) Subsektor Indutri televisi

2) Subsektor Industri Radio

3) Subsektor Industri IT, Software and computer services

4) Subsektor Industri Arsitektur

5) Subsektor Indutri Publishing 


\subsubsection{Sampel}

Menurut Riduwan. Kuncoro (2007), mengatakan bahwa sampel adalah bagian dari populasi (sebagian atau wakil yang diteliti). Sampel penelitian adalah sebagian dari populasi yang diambil sebagai sumber data dan dapat mewakili seluruh populasi.

Menurut Singgih Santoso (2011:70) untuk model Structural Equation Modeling (SEM) dengan jumlah variabel konstruk sampai dengan lima buah, dan setiap konstruk dijelaskan oleh tiga atau lebih indikator, jumlah sampel 100-150 data sudah dianggap memadai.

Penentuan jumlah sampel berdasarkan pendapat Hair, dkk (1995:72) dalam Ghozali (2008a:64) bahwa analisis data multivariat menggunakan SEM, pada umumnya metode estimasi menggunakan maximum likelihood estimation (MLE) disamping akternatif metode lain. MLE akan efektif pada jumlah sampel antara 150400. Menurut Haryono (2012:253), jumlah sampel juga dapat ditentukan dengan 5-10 per parameter. Dalam penelitian ini terdapat tiga konstruk dengan total 28 parameter.

\subsubsection{Teknik Pengambilan Sampel}

Pemilihan sampel penelitian ini didasarkan pada metode simple random sampling. Simple random sampling merupakan teknik pengambilan sampel yang memberikan kesempatan yang sama kepada setiap anggota yang ada dalam suatu populasi untuk dijadikan sampel. Syarat untuk dapat dilakukan teknik simple random sampling adalah : anggota populasi tidak memiliki strata sehingga relatif 
homogeni dan adanya kerangka sampel yaitu merupakan daftar elemen-elemen populasi yang dijadikan dasar untuk pengambilan sampel.

\subsection{Metode Pengumpulan Data}

Metode pengumpulan data dalam penelitian ini adalah termasuk penelitian lapangan yaitu dengan cara mengumpulkan data pokok (data primer) dari suatu sampel dengan menggunakan instrument kuesioner yang menjelaskan dan menguji hipotesis (explanatory).

Operasional penyebaran kuesioner ini dilakukan dengan cara mendatangi secara langsung ke kantor-kantor industri kreatif sebagaimana ditentukan dalam populasi dan memberikan kuesioner, yang berisi daftar pernyataan terstruktur yang ditujukan kepada responden, mulai dari manajer, bagian keuangan, bagian TI sampai karyawan bagian operasional. Responden lalu memilih salah satu alternatif jawaban yang sesuai dengan opininya. Demikian pula pengambilannya diambil sendiri dari responden sesuai dengan waktu yang dijanjikan.

\subsection{Metode Analisis}

Dalam penelitian ini analisis diawali dengan pengumpulan dan pengolahan data yang diperoleh dari kuesioner dengan menggunakan skala likert, yang kemudian diuji validitas dan reliabilitas serta normalitasnya. Kemudian hasil pengolahan data tersebut dianalisis lebih lanjut untuk menjawab tujuan-tujuan penelitian, dengan menggunakan Structural Equation Modelling. 


\subsubsection{Skala Likert}

Menurut Haryadi Sarjono dan Winda Julianita (2011), skala likert adalah skala yang digunakan untuk mengukur sikap, pendapat, dan persepsi seseorang atau sekelompok orang terhadap suatu kejadian atau keadaan sosial, dimana variablel ang akan diukur dijabarkan menjadi indikator variabel kemudian indikator tersebut dijadikan sebagai titik tolak untuk menyusun item-item pernyataan.

Skala likert memiliki dua bentuk pertanyaan, yaitu pernyataan positif dan pernyataan negatif. Pernyataan positif diberi skor 1 untuk jawaban sangat setuju, skor 2 untuk jawaban tidak setuju, skor 3 untuk jawaban setuju dan skor 4 untuk jawaban sangat setuju. Sementara untuk pernyataan negatif diberi skor 1 untuk jawaban sangat setuju, skor 2 untuk jawaban setuju, skor 3 untuk jawaban tidak setuju dan skor 4 untuk jawaban sangat tidak setuju.

\subsubsection{Analisis Faktor Konfirmatori (Confirmatory Factor Analysis/ CFA)}

Analisis faktor konfirmatori dirancang untuk menguji unidimensionalitas dari suatu konstruk teoritis atau juga sering disebut menguji validitas suatu konstruk teoritis. Dalam penelitian ini terdapat satu variabel eksogen dan dua variabel endogen. Variabel eksogen yang akan diuji ini adalah Kompetensi Teknologi Informasi dan Komunikasi (TIK) dan variabel endogennya yaitu Manajemem Pengetahuan dan Inovasi. 


\subsubsection{Analisis Model Struktural}

Tahap selanjutnya setelah Confirmatory Factor Analisys sebagai tahapan analisis model pengukuran, adalah analisis model struktural atau analisis Structural Equation Modelling. Analisis hasil pengolahan data pada tahap full model ini dilakukan dengan melakukan uji kesesuaian dan uji statistik. Dalam uji ini merujuk pada kriteria model fit sebagaimana telah dijelaskan pada bab sebelumnya.

\subsubsection{Uji Normalitas}

Estimasi dengan Maximum Likelihood menghendaki variabel observed harus memenuhi asumsi normalitas multivariate. Oleh karena itu perlu dilakukan pengujian untuk melihat tingkat normalitas secara multivariate terhadap data yang digunakan dalam penelitian ini.

Evaluasi normalitas multivariate dengan Amos 21.0.0 dilakukan dengan menggunakan kriteria critical ratio (c.r) dari Multivariate pada kurtosis, apabila berada pada rentang antara - 2,58 sampai 2,58 berarti data berdistribusi normal secara multivariate

\subsubsection{Data Outliers}

Outliers merupakan observasi atau data yang memiliki karakteristik unik yang terlihat sangat berbeda jauh dari observasi-observasi yang lain dan muncul dalam bentuk nilai ekstrim, baik untuk sebuah variabel tunggal maupun variabel-variabel kombinasi (Hair,et all, dalam Ghozali, 2008a:227). 
Deteksi terhadap multivariate outliers dilakukan dengan memperhatikan nilai Mahalanobis Distance. Jarak mahalonobis untuk tiap-tiap observasi akan menunjukkan sebuah observasi data terhadap nilai rata-rata (centroid) nya.

\subsubsection{Multicolinearity dan Singularity}

Selanjutnya untuk melihat apakah terdapat multikolinearitas dan singularitas dalam sebuah kombinasi variabel. Menurut (Haryono dan Wardoyo 2012:311) Pengujian untuk melihat apakah terdapat multicolinearitas dan singularity dalam sebuah kombinasi variabel, indikasi adanya multikolinearitas dan singularitas dapat diketahui melalui nilai determinan matriks kovarian sampel yang benar-benar kecil, atau mendekati nol.

\subsubsection{Uji Reabilitas Konstruk}

Reliabilitas merupakan ukuran konsistensi internal dari indikator-indikator sebuah variabel bentukan yang menunjukkan derajat sampai dimana masingmasing indikator itu mengindikasikan sebuah variabel bentukan yang umum. Uji reliabilitas dalam SEM dapat diperoleh melalui rumus sebagai berikut (Ghozali, 2008:233) :

$$
\begin{array}{ll}
\text { Construct-Reliability } & =\left(\sum \chi\right)^{2} \div\left(\sum \chi\right)^{2}+\sum \in J \\
\text { Variance Extract } & =\sum \chi^{2} \div \sum \chi^{2}+\sum \in J
\end{array}
$$




\section{Keterangan :}

Standard loading $(\chi)$ didapat dari standardized loading untuk tiap-tiap indikator yang didapat dari hasil perhitungan komputer.

$\sum \in$ adalah measurement error dari tiap indikator, measurement error dapat diperoleh dari 1- reliabilitas indikator, tingkat reliabilitas yang dapat diterima adalah $\geq 0,7$.

\subsubsection{Discriminant Validity}

Dalam analisis SEM diperlukan suatu analisis untuk mengukur seberapa jauh suatu konstruk benar-benar berbeda dari konstruk lainnya, tahap ini disebut dengan uji Descriminant Validity. Nilai Descriminant Validity menjadi ketentuan dalam menganalisis apakah suatu konstruk unik dan mampu menangkap fenomena yang diukur. Uji Descriminant Validity dilakukan dengan membandingkan nilai akar kuadrat dari Average Variance Extracted (AVE).

\subsubsection{Pengujian Hipotesis}

Pengujian dilakukan terhadap dua hipotesis yang diajukan. Pengujian dilakukan dengan menggunakan nilai t-value dengan tingkat signifikansi 0,05 . Nilai t-value dalam program AMOS 21.0.0 merupakan nilai Critical Ratio (C.R) pada Regression Weights dari fit model. Jika nilai C.R. $\geq 1,967$ atau nilai probabilitas $(\mathrm{P}) \leq 0,05$ maka $\mathrm{H} 0$ ditolak (hipotesis penelitian diterima). 


\section{DAFTAR ACUAN}

Darroch, Jenny (2003), "Developing a measure of knowledge management behavior and practices", Journal of Knowledge Management, Vol.7, No.5, pp.41-54.

Darroch., Jenny, (2005), "Knowledge management, innovation and firm performance", Journal Of Knowledge Management Vol. 9 NO. 32005

Darroch.,Jenny, Rod McNaughton (2002), "Examining the link between knowledge management practices and types of innovation"

Haryono Siswoyo.Prof.Dr.H, Parwoto Wardoyo, ST. MM,(2012). Structural Equation Modeling untuk Penelitian Manajemen Menggunakan AMOS 18.0.0. PT Intermedia Personalia Utama, ISBN: 978-979-99568-1-1

López, Susana Pérez., Peón, José Manuel Montes., and Ordás, Camilo José Vázquez (2009) "Information Technology as an Enabler of Knowledge Management: An Empirical Analysis", Department of Business Administration, University of Oviedo, Avda. del Cristo, s/n 33071, Oviedo, Spain 


\section{DAFTAR PUSTAKA}

Abou-Zeid, E.S. (2002) “A Knowledge Management Reference Model.” Journal of Knowledge Management, Vol. 6, No. 5, pp. 486-499.

Ackoff, R.L. (1999), Re-creating the corporation: a design of organizations for the 21st century, Oxford University Press.

Alavi, M.L., and D.E. Leidner. (2001). Review: Knowledge management and knowledge management systems: Conceptual foundations and research issues. MIS Quarterly 25(1): 107-136.

Antonelli, C., (1999), "The evolution of the industrial organisation of the production of knowledge", Cambridge Journal of Economics, Vol 23, pp 243-260.

Bhatt, G. (2000) “Organizing knowledge in the knowledge development cycle.” Journal of Knowledge Management, Vol. 4, No. 1, pp. 15-26.

Bibikas D., Kourtesis D., Paraskakis I., Bernardi A., Sauermann, L., Apostolou D., Mentzas G., \& Vasconcelos A.C. (2008). Organisational Knowledge Management Systems in the Era of Enterprise 2.0: The case of OrganiK. 11th International Conference on Business Information Systems, BIS, Innsbruck, Austria 5-7 May. Online. Available from: http://ftp.informatik.rwth-aachen.de/Publications/CEURWS/Vol-333/saw4.pdf.

Booz Allen Hamilton (1982), New Products for the 1980s, Booz Allen Hamilton, New York, NY. 
Borghini, S. (2005). Organizational creativity: Breaking equilibrium and order toinnovate. Journal of Knowledge Management, 9(4), 19-33.

Brown, J., and P. Duguid. (1998). Organizing knowledge. California Management Review 40(3): 90-111.

Bukowitz, W., \& Williams, R. (1999), The Knowledge Management Fieldbook, Financal Times/Prentice Hall.

Capon N, Glazer R. 1987. Marketing and technology: a strategic coalignment. Journal of Marketing 51(July): 1-14.

Carneiro, A., (2000), "How does knowledge management influence innovation and competitiveness?”, Journal of Knowledge Management, Vol 4 No 2, pp 87-98.

Chandrashekaran,.Murali, Raj Mehta; Rajesh Chandrashekaran; Rajdeep Grewal (199), "Market Motives, Distinctive Capabilities, and Domestic Inertia: A Hybrid Model of Innovation Generation", Journal of Marketing Research; Feb 1999; 36, 1, ABI/INFORM Global

Choi, B., S.K. Poon, and J.G. Davis. 2008. Effects of knowledge management strategy on organizational performance: A complementarity theory-based approach. Omega 36: 235-251.

Choy, C. S., Yew, W. K., \& Lin, B. (2006). Criteria for measuring KM performanceoutcomes in organizations. Industrial Management \& Data Systems, 106(7),917-936. 
Choy, C. S., Yew, W. K., \& Lin, B. (2006). Criteria for measuring KM performanceoutcomes in organizations. Industrial Management \& Data Systems, 106(7),917-936

Chua, A. (2002) “The Influence of Social Interaction on Knowledge Creation.” Journal of Intellectual Capital, Vol. 3, No. 4, pp. 375-392.

Cook, S.D., and D. Yanow. (1993). Culture and organizational learning. Journal of Management Inquiry 2(4): 373-390.

Cranfield University, “The Cranfield/Information Strategy Knowledge Survey: Europes State of the Art in Knowledge Management," The Economist Group, 1998

Cross, R., and L. Baird. 2000. Feeding organizational memory: Improving on knowledge management's promise to business performance. In Strategic learning in a knowledge economy. Individual, collective and organizational learning process, ed. L. Robert, J. Cross, and S.B. Israelit, 69-90. Oxford: Butterworth-Heinemann.

Damanpour, F., \& Evan, W. M. 1984. Organizational Innovation and Performance: The Problem of "Organizational Lag". Administrative Science Quarterly, 29(3): 392409.

Davenport T. and Volpel S. (2001), 'The rise of knowledge towards attention management', Journal of Knowledge Management, 5(3), pp. 212-221.

Davenport, T., Javenpaa., and Beer, M.C. (1996). 'Successful knowledge management projects', Sloan Management Review, 39 (2), pp. 43-57. 
Davenport,Thomas H. and Lawrence Prusak (2000) "Working Knowledge: How Organizations Manage What They Know", ACM: Ubiquity - Working Knowledge: How Organizations Management

Day, G., (1994), “The capabilities of market-driven organizations”, Journal of Marketing, Vol 58, October, pp 37-52.

Departemen Perdagangan Republik Indonesia (2008), "Rencana Pengembangan Ekonomi Kreatif Indonesia 2009-2015”, Studi Industri Kreatif Indonesia

Dosi, G., (1988), “Sources, procedures and microeconomic effects of innovation”, Journal of Economic Literature, Vol 26, September, pp 1120-1171.

Dove, R., (1999), "Knowledge management, response ability, and the agile enterprise", Journal of Knowledge Management, Vol 3 No 1, pp 18-35.

Drucker P.F. (1995) Managing in a Time of Great Change, Butterworth-Heinemann Ltd, Oxford

Dunamis Organization Services, "Successful Implementation Of Km In Indonesia". Dunamis Publishing 2013.

Fahey, L. and L. Prusak, (1998), “The eleven deadliest sins of knowledge management”, California Management Review, Vol 40 No 3, pp 265-276.

Fox, S. 2000. Communities of practice, foucault and actor network theory. Journal of Management Studies 37(6): 853-867. 
Franco, M., and S. Mariano. 2007. Information technology repositories and knowledge management proceses: A qualitative analysis. VINE: The Journal of Information and Knowledge Management Systems 37(4): 440-451.

Frappaolo, Carl (2006), Knowledge Management, Capstone Publishing Ltd(A Wiley Company), West Sussex, England.

Frost,.Alan M.Sc., (2010, update 2013), "Defining Knowledge, Information, Data", http://www.knowledge-management-tools.net/. Diakses 24 Agustus 2014

Gallupe B. (2001). Knowledge Management Systems: Surveying the landscape. International Journal of management Reviews, 3 (1), 61-77.

Gatignon, H. and T. S. Robertson, (1985), “A propositional inventory for new diffusion research”, Journal of Consumer Research, Vol 11, pp 849-867.

Gherardi, S., and D. Nicolini. 2002. Learning in a constellation of interconnected practices: Canon or dissonance? Journal of Management Studies 39(4): 419-436.

Gloet, M., \& Terziovski, M. (2004). Exploring the relationship between knowledgemanagement practices and innovation performance. Journal of ManufacturingTechnology Management, 15(5), 402-409.

Granstrand O. 1982. Technology, Management, and Markets. St Martin’s Press: New York.

Grant, R. M., (1996), "Toward a knowledge-based theory of the firm", Strategic Management Journal, Vol 17,Winter Special Issue, pp 109-122.

Grundstein M. (2008). Assessing the enterprise's knowledge management maturity level. International Journal of Knowledge and Learning, 4 (5), 415-426. 
Gunasekaran, A., P. Love, F. Rahimi, and R. Miele. 2001. A model of investment justification in information technology projects. International Journal of Technology Management 21: 349-364.

Haryadi Sarjono, Winda Julianita. 2011. SPSS vs LISREL sebuah pengantar Aplikasi untuk Riset. Penerbit Salemba Empat. Jakarta

Haryono Siswoyo.Prof.Dr.H, Parwoto Wardoyo, ST. MM,(2012). Structural Equation Modeling untuk Penelitian Manajemen Menggunakan AMOS 18.0.0. PT Intermedia Personalia Utama, ISBN: 978-979-99568-1-1

Hawkins, B. Libraries, knowledge management and higher education in an electronic environment', In: Proceedings of the American Library and Information Association Conference, Chicago, Illinois, 2000.

Hayes, M.; Walsham, G. (2003). "Knowledge sharing and ICTs: A relational perspective". In Easterby-Smith, M.; Lyles, M.A. The Blackwell Handbook of Organizational Learning and Knowledge Management. Malden, MA: Blackwell. pp. 54-77. ISBN 978-0-631-22672-7.

Hong, J. (1999) "Structuring for Organizational Learning." The Learning Organization, Vol. 6, No. 4, pp. 173-185.

Huber, G. "Organizational Learning: The Contributing Processes and the Literatures", Organization Science, Vol. 2, no. 1, 1991, pp. 88-115.

Huber, G. 1990. A theory of the effects of advanced information technologies on organizational design, intelligence, and decision making. Academy of Management Review 15(1): 47-71. 
Huber, G. 1991. Organizational learning: Contributing processes and the literatures. Organizational Science 2: 88-115.

Indriantoro, dan Supomo, 2002.Metodologi Penelitian Bisnis untuk Akuntansi dan Manajemen, Edisi Pertama, BPFE-Yogyakarta, Yogyakarta.

Kohli, A. K. and B. J. Jaworksi, (1990), "Market orientation the construct, research propositions and managerial implications”, Journal of Marketing, Vol 54,:pp 1-18.

Krogh, V. G. and Roos J. (1996) Managing Knowledge, Sage, London.

Krone, K.J., Jablin, F.M., and Putnam, L.L. "Communication Theory and Organized Communication: Multiple Perspectives", In Jablin, F.M., Putnam, L.L., Roberts, K.H., and Porter, L.W. (eds.), Handbook of Organizational Communication, Sage Publications. 1987.

Lave, J., and E. Wenger. 1991. Situated learning: Legitimate peripheral participation . Cambridge:Cambridge University Press.

Lee, S.M., and S. Hong. 2002. An enterprise-wide knowledge management system infrastructure. Industrial Management \& Data Systems 102(1): 17-25.

Leonard, D, \& Sensiper, S. (1998). The role of tacit knowledge in group innovation.California Management Review, 40(3), 112-132.

Leonard-Barton D. 1995. Wellsprings of Knowledge. Harvard Business School Press: Boston, MA.

Levitt, B., and J. March. 1988. Organizational learning. American Review of Sociology 14: $319-340$ 
Lisa Quast (2012, August 20), "Why Knowledge Management Is Important To The Success Of Your Company", http://www.forbes.com/. Diakses 24 Agustus 2014

Maier R. (2007). Knowledge Management System: Information and Communication Technologies for Knowledge Management. Third Edition. Springer, ISBN 978-3540-71407-4.

Maier, J.L., R.K. Rainer, and C.A. Snyder. 1997. Environmental scanning for information technology: An empirical investigation. Journal of Management Information Systems 14(2): 177-201.

Malhotra, Y. (2000) “Knowledge Management for E-Business Performance: Advancing Information Strategy to Internet Time.” Information Strategy: The Executive's Journal, pp.5-16.

Maryann P. Feldman, Ian I. Stewart. Knowledge Transfer and Innovation: A Review of the Policy Relevant Literature. 2006. Queen's Printer for Ontario.

Massey, A. P., Montoya-Weiss, M. M., \& O’Driscoll, T. M. (2002). Knowledge managementin pursuit of performance: Insights from Nortel networks. MIS Quarterly,26(3), 269-289.

McCann, J.E., and M. Buckner. 2004. Strategically integrating knowledge management initiatives.Journal of Knowledge Management 8: 47-63.

Michel GRUNDSTEIN, Camille ROSENTHAL-SABROUX. A Sociotechnical Approach of Knowledge Management within the Enterprise: The MGKME Model. 2007. LAMSADE Paris Dauphine University, France 
Mitcham C, Mackey R. 1983. Philosophy and Technology: Readings in the Philosophical Problems of Technology. Free Press: New York.

Nelson RR, Peck MJ, Kalachek ED. 1967. Technology, Economic Growth, and Public Policy. Brookings Institution: Washington, DC.

Nickols.,Fred (2000), "The Knowledge in Knowledge Management", http://www.nickols.us/. Dikases 24 Agustus 2014

Nonaka, I. and Takeuchi, H (1995). The Knowledge Creating Company (New York, NY: Oxford University Press, 1995).

Nonaka, I., and Takeuchi, H., (1996). The Theory of Organizational Knowledge Creation. International Journal of Technology Management, vol 11, no 7/8, 1996

Nonaka, I., Konno, N. (1998) "The concept of "Ba": building a foundation for knowledge creation”, California Management Review, Vol.40, No.3, Spring, pp.40-54.

O'Connor, G. C., (1998), "Market learning and radical innovation: a cross case comparison of eight radical innovation projects”, Journal of Product Innovation Management, Vol 15, pp 151-166.

Olivera, F. 2000. Memory systems in organizations: An empirical investigation of mechanisms for knowledge collection storage and access. Journal of Knowledge Management 37(6): 811-832.

Priyatno, Dwi. (2008). Mandiri Belajar SPSS Untuk Analisis Data dan Uji Statistik, Mediakom. 
Quintas, P., Lefrere, P. and Jones, G. (1997). KNowledge Management: A Strategic Agenda. Long Range Planning, pp. 385-391.

Reardon, J., R. Hasty, and B. Coe. 1996. The effect of Information technology on productivity in retailing. Journal of Retailing 72(4): 445-461.

Rice, M. P., G. C. O'Connor, L. S. Peters and J. G. Morone, (1998), "Managing discontinuous innovation”, Research-Technology Management, Vol 41 No, 3, pp $52-58$.

Riduwan. (2004), Metode dan Teknik Menyusun Tesis, Alfabeta Bandung.

Riduwan. Kuncoro, E. A. (2007). Cara Menggunakan dan Memaknai Analisis Jalur (Path Analysis). Bandung: Alfa Beta.

Rory L.Chase. 2003 Most Admired Knowledge Enterprises (MAKE) in Japan Report, Executive Summary. 2004. Teleos - The KNOW Network.

Šajeva.,Svetlana (2010), "The Analysis Of Key Elements Of Socio-Technical Knowledge Management System", Ekonomika Ir Vadyba: 2010. 15, ISSN 1822-6515

Santoso, S. 2010. Statistik Multivariat Konsep dan Aplikasi dengan SPSS. Jakarta: PT Elex Media Komputindo.

Sedighi.,Mehri and Ammar Jalalimanesh (2014), "Mapping research trends in the field of knowledge management", Malaysian Journal of Library \& Information Science, Vol. 19, no. 1, 2014: 71-85

Sekaran, Uma, 2006. Metodologi Penelitian Untuk Bisnis, Jakarta: Salemba Empat. 
Shavelson.,Richard and Maria Araceli Ruiz-Primo (2003), "Evaluating New Approaches to Assessing Learning", The Regents of the University of California

Siregar,. Sofyan, MM.Ir (2013), “Metode Penelitian Kuantitatif”, Kencana Prenada Media Group, Jakarta

Sugiyono. (2011). Metode Penelitian Kualitatif,. Bandung: Alfabeta.

Sugiyono.(1999). Statistika Untuk Penelitian. Bandung: CY Alfabeta

Svetlana Šajeva. The Analysis Of Key Elements Of Socio-Technical Knowledge Management System. 2010. Economics And Management: 2010. 15. ISSN 18226515

Taylor, J.C. 1971. Technology and planned organizational change . Ann Arbor, MI: BraunBrumfield.

Teece, D. J., (2000), “Strategies for managing knowledge assets: the role of firm structure and industrial context", Long Range Planning, Vol 33, pp 35-54.

Teece, D., "Capturing Value from Knowledge Assets: The New Economy, Market for Know-How, and Intangible Assets, “ California Management Review, Vol. 40, No. 3, 1998, pp. 55-79

Tippins, M.R., and R.S. Sohi. 2003. TI competency and firm performance: Is organizational learning a missing link? Strategic Management Journal 24(8): 745761.

Tushman, M. and P. Anderson, (1986), “Technological discontinuities and organizational environments", Administrative Science Quarterly, Vol 31, pp 439-465. 
Tuzovsky A.F., \& Yampolsky V.Z. (2003). The system approach to knowledge management systems designing and development. Proceedings of the 7th KoreaRussia International Symposium. KORUS 2003, 319-323.

Veryzer Jr., R. W., (1998), "Discontinuous innovation and the new product development process", Journal of Product Innovation Management, Vol 15, pp 304-321.

von Krogh, G. and Roos, J.(1996) "A Tale of the Unfinished", Strategic Management Journal, Vol. 17, No. 9, 1996: 729-739

Von Krogh, G., Ichijo, K. and Nonaka, I. (2000), Enabling Knowledge Creation, Oxford University Press, New York.

Wellman, J. L. (2009). Organizational Learning: How Companies and Institutions Manage and Apply Knowledge Palgrave Macmillian.

Wenger, E. 1998. Communities of practice: Learning, meaning and identity . Cambridge: Cambridge University Press.

Wiig, K.M. 1997. Integrating intellectual capital and knowledge management. Long Range Planning 30(3): 399-405.

Workman Jr, J. P., (1993), “Marketing's limited role in new product development in one computer systems firm”, Journal of Marketing Research, Vol 30, November, pp $405-421$

Zaim, S. (2000) “Kıyaslama (Benchmarking) Yolu ile Daha Iyiye Ulaşmanın Yolu.” Prof. Dr. Nusret Ekin’e Armağan, Tühis, pp. 996-974. 
Zehir, Cemal, Emine Yilmaz, Harun Velioglu (2008) "The Impact of Information Technology Practices and Organizational Learning on Firm Inovation and Performance" Journal of Global Strategic Management 
Mahasiswa Magister Manajemen Sistem Informasi

Universitas Bina Nusantara

Jakarta

Phone : 085668174530

URL : http://mascosmaseko.blogspot.com/

Email : costmust@gmail.com

FB : $\quad$ https://www.facebook.com/mascosmaseko

Hal : Permohonan Pengisian Kuesioner Penelitian

Kepada

Yth. Bapak/Ibu/Sdr. Responden

Di tempat

Dengan hormat,

Sehubungan dengan syarat terselesainya pendidikan Magister Manajemen Sistem Informasi yang sedang saya tempuh, maka saya:

Nama : Cosmas Eko Suharyanto

Status : Mahasiswa Universitas Bina Nusantara

NIM : 1322202122

Dengan rendah hati memohon kesediaan Bapak/Ibu/Saudara untuk menjadi Responden dalam penelitian saya dengan mengisi isian kuesioner yang terlampir dalam surat ini.

Angket ini bukanlah tes psikologi dari atasan atau pihak manapun, maka dari itu, mohon agar tidak takut atau ragu-ragu dalam memberikan jawaban yang sejujurnya. Artinya semua jawaban yang diberikan adalah benar sesuai dengan kondisi yang dirasakan.

Topik penelitian saya adalah tentang Manajemen Pengetahuan (Knowledge Management), dengan judul "Peran Teknologi Informasi dan Komunikasi (TIK) sebagai enabler Manajemen Pengetahuan dalam Membawa Inovasi Pada Industri Kreatif Di Batam".

Kuesioner ini ditujukan kepada para pelaku industri kreatif di kota Batam, yang terdiri dari empat belas (14) sub sektor: Periklanan, Penerbitan dan Percetakan, TV dan Radio, Video dan Fotografi, Musik, Seni Pertunjukan, Arsitektur, Desain, Fesyen, Kerajinan, Pasar Barang Seni, Permainan Interaktif, Layanan Komputer dan Piranti Lunak, Penelitian dan Pengembangan.

Setiap jawaban yang Bapak/Ibu/Saudara berikan merupakan bantuan yang tidak ternilai harganya bagi penelitian ini, atas perhatian dan bantuannya, saya mengucapkan limpah terimakasih.

Batam, 01 Februari 2015

Hormat saya,

\section{Cosmas Eko Suharyanto}


PETUNJUK PENGISIAN:

1. Mohon Bpk./Ibu/Sdr. Responden untuk menjawab seluruh pertanyaan yang ada

2. Berilah tanda check list $(\checkmark)$ pada kolom yang tersedia dan pilih sesuai dengan keadaan yang sebenarnya.

3. Terdapat lima alternative jawaban, yaitu:

- 5 : Sangat Setuju

- 4 : Setuju

- 3 : Cukup

- 2 : Tidak Setuju

- 1 : Sangat Tidak Setuju

\section{DAFTAR ISTILAH :}

- Pengetahuan/knowledge adalah informasi yang mengubah sesuatu atau seseorang, hal itu terjadi ketika informasi tersebut menjadi dasar untuk bertindak, atau ketika informasi tersebut memampukan seseorang atau institusi untuk mengambil tindakan yang berbeda atau tindakan yang lebih efektif dari tindakan sebelumnya.

- Kodifikasi \& sistem administrasi pengetahuan : ilmu pengetahuan/pengalaman/best pratice yang sudah dibuat dalam sebuah penyimpanan; missal buku manual/buku petunjuk, SOP, tutorial, work sheet/ kertas kerja, dll.

- Mereposisi produk/layanan/program : merubah salah satu dari elemen strategi pemasaran agar target pasar mempunyai persepsi yang dapat membedakan suatu produk/ layanan/ program dari pesaing

\section{KARAKTERISTIK RESPONDEN:}

a. Jenis Usaha

: $\square$ Advertising \& Marketing

$\square$ Film/TV $\quad \square$ Radio $\square$ Video and Photography

$\square$ IT, software and computer services

Music, performing and visual arts

Arsitektur

Design \& Fashion

Publishing

b. Jabatan

c. Usia tahun

d. Jenis Kelamin

e. Pendidikan terakhir 
Mahasiswa Magister Manajemen Sistem Informasi

Universitas Bina Nusantara

Jakarta

Phone : 085668174530

URL : http://mascosmaseko.blogspot.com/

Email : costmust@gmail.com

FB : https://www.facebook.com/mascosmaseko

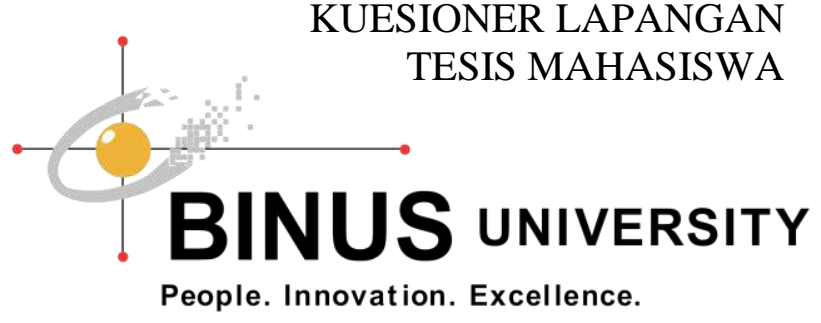

f. Nilailah Perusahaan Anda, sesuai persepsi Anda !

1 : Sangat Tidak Setuju, 2 : Tidak Setuju, 3 : Cukup, 4 : Setuju, 5 : Sangat Setuju

KOMPETENSI TIK (ICT Competency)

\begin{tabular}{|c|c|c|c|c|c|c|c|c|}
\hline YARIARFI & \multicolumn{2}{|r|}{ INDIKATOR } & KO & \multicolumn{5}{|c|}{ PENILAIAN } \\
\hline & & & & 1 & 2 & 3 & 4 & 5 \\
\hline \multirow{3}{*}{$\begin{array}{l}\text { Pengetahuan } \\
\text { TIK } \\
\text { (ICT Knowledge) }\end{array}$} & 1. & $\begin{array}{l}\text { Secara umum, staf technical support IT } \\
\text { kami memiliki pengetahuan yang cukup } \\
\text { untuk menangani sistem berbasis } \\
\text { komputer }\end{array}$ & K1 & & & & & \\
\hline & 2. & $\begin{array}{l}\text { Perusahaan/organisasi kami memiliki } \\
\text { keahlian teknis berbasis komputer yang } \\
\text { tinggi }\end{array}$ & K2 & & & & & \\
\hline & 3. & $\begin{array}{l}\text { Kami memahami (berpengetahuan) } \\
\text { tentang inovasi komputer yang baru } \\
\text { (update technology) }\end{array}$ & K3 & & & & & \\
\hline & & & & & & & & \\
\hline \multirow{4}{*}{$\begin{array}{c}\text { Operasi TIK } \\
\text { (ICT Operations) }\end{array}$} & 1. & $\begin{array}{l}\text { Kami secara rutin menggunakan sistem } \\
\text { berbasis komputer untuk mengakses } \\
\text { informasi dari basis data (database) }\end{array}$ & 01 & & & & & \\
\hline & 2. & $\begin{array}{l}\text { Kami menggunakan sistem berbasis } \\
\text { komputer untuk menganalisis pelanggan } \\
\text { dan informasi pasar. }\end{array}$ & $\mathrm{O} 2$ & & & & & \\
\hline & 3. & $\begin{array}{l}\text { Kami sering menggunakan sistem } \\
\text { pendukung keputusan ( decision-support } \\
\text { systems) ketika mengelola informasi } \\
\text { pelanggan }\end{array}$ & O3 & & & & & \\
\hline & 4. & $\begin{array}{l}\text { Kami telah menetapkan prosedur untuk } \\
\text { mengumpulkan informasi pelanggan dari } \\
\text { sumber online }\end{array}$ & $\mathrm{O4}$ & & & & & \\
\hline \multirow{4}{*}{$\begin{array}{l}\text { Infrastruktur TIK } \\
\text { (ICT Infrastructure) }\end{array}$} & & & & & & & & \\
\hline & 1 & $\begin{array}{l}\text { Perusahaan/organisasi kami memiliki } \\
\text { departemen Manajemen Sistem Informasi } \\
\text { (IT) resmi/divisi IT }\end{array}$ & 11 & & & & & \\
\hline & 2 & $\begin{array}{l}\text { Perusahaan kami mempekerjakan seorang } \\
\text { manajer khusus yang bertugas utama } \\
\text { meliputi pengelolaan teknologi informasi }\end{array}$ & 12 & & & & & \\
\hline & 3 & $\begin{array}{l}\text { Komputer di perusahaan kami } \\
\text { dihubungkan dengan jaringan komputer }\end{array}$ & 13 & & & & & \\
\hline
\end{tabular}


Mahasiswa Magister Manajemen Sistem Informasi

Universitas Bina Nusantara

Jakarta

Phone : 085668174530

URL : http://mascosmaseko.blogspot.com/

Email : costmust@gmail.com

FB : https://www.facebook.com/mascosmaseko

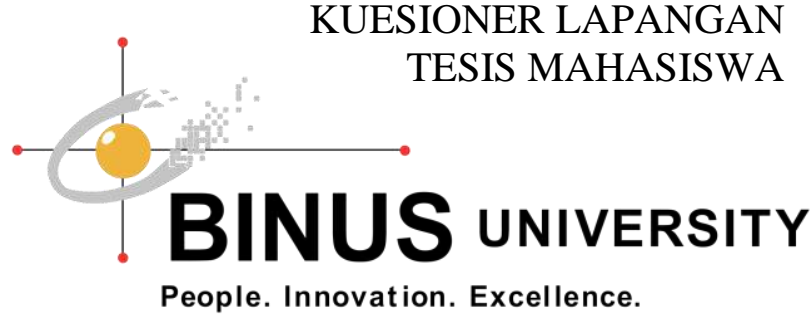

\begin{tabular}{|l|l|l|l|l|l|l|l|l|}
\hline & 4 & $\begin{array}{l}\text { Perusahaan/organisasi kami menciptakan } \\
\text { software/ aplikasi sendiri yang fleksibel } \\
\text { yang dapat disesuaikan sesuai kebutuhan }\end{array}$ & 14 & & & & \\
\hline & & & & & & & \\
\hline
\end{tabular}

PROSES MANAJEMEN PENGETAHUAN (KNOWLEDGE MANAGEMENT PROCES)

\begin{tabular}{|c|c|c|c|c|c|c|c|c|}
\hline \multirow{2}{*}{ VARIABEL } & \multicolumn{2}{|r|}{ INDIKATOR } & \multirow{2}{*}{$\begin{array}{l}K O \\
D E\end{array}$} & \multicolumn{5}{|c|}{ PENILAIAN } \\
\hline & & & & 1 & 2 & 3 & 4 & 5 \\
\hline \multirow{4}{*}{$\begin{array}{l}\text { Knowledge } \\
\text { Generation }\end{array}$} & 1. & $\begin{array}{l}\text { Kami secara teratur bertemu dengan } \\
\text { pelanggan kami untuk mencari tahu apa } \\
\text { kebutuhan/harapan mereka }\end{array}$ & MP1 & & & & & \\
\hline & 2. & $\begin{array}{l}\text { Perusahaan/Organisasi kami memiliki } \\
\text { hubungan dengan para professional dan } \\
\text { praktisi sesuai dengan bidang usaha kami }\end{array}$ & MP2 & & & & & \\
\hline & 3. & $\begin{array}{l}\text { Kami memiliki sistem yang memungkinkan } \\
\text { kami belajar dari kesuksesan organisasi lain }\end{array}$ & MP3 & & & & & \\
\hline & 4 & $\begin{array}{l}\text { Ide-ide dan pendekatan-pendekatan } \\
\text { prestasi kerja yang baru dicoba secara } \\
\text { terus-menerus }\end{array}$ & MP4 & & & & & \\
\hline & & & & & & & & \\
\hline \multirow{4}{*}{$\begin{array}{c}\text { Knowledge } \\
\text { Transfer }\end{array}$} & 1. & $\begin{array}{l}\text { Semua karyawan tahu visi, misi dan tujuan } \\
\text { perusahaan }\end{array}$ & MP5 & & & & & \\
\hline & 2. & $\begin{array}{l}\text { Pertemuan berkala diadakan untuk } \\
\text { menginformasikan semua karyawan } \\
\text { tentang inovasi terbaru dalam perusahaan }\end{array}$ & MP6 & & & & & \\
\hline & 3. & $\begin{array}{l}\text { Perusahaan menjamin dan mendukung } \\
\text { SHARING tentang praktik-praktik terbaik } \\
\text { (best practice) diberbagai bidang kegiatan }\end{array}$ & MP7 & & & & & \\
\hline & 4. & $\begin{array}{l}\text { Kerja Tim (team work) sudah menjadi } \\
\text { praktek yang sangat umum di perusahaan } \\
\text { (sudah membudaya) }\end{array}$ & MP8 & & & & & \\
\hline \multirow{3}{*}{$\begin{array}{l}\text { Knowledge } \\
\text { Codification \& } \\
\text { Storage }\end{array}$} & 1 & $\begin{array}{l}\text { Basis data (database) di perusahaan kami } \\
\text { selalu terkini/update }\end{array}$ & MP9 & & & & & \\
\hline & 2 & $\begin{array}{l}\text { Karyawan memanfaatkan basis data - } \\
\text { (database) untuk berbagai hal }\end{array}$ & MP10 & & & & & \\
\hline & 3 & Kodifikasi dan sistem administrasi & MP11 & & & & & \\
\hline
\end{tabular}


Mahasiswa Magister Manajemen Sistem Informasi

Universitas Bina Nusantara

Jakarta

Phone : 085668174530

URL : http://mascosmaseko.blogspot.com/

Email : costmust@gmail.com

FB : https://www.facebook.com/mascosmaseko

\begin{tabular}{|l|l|l|l|l|l|l|l|}
\hline & $\begin{array}{l}\text { pengetahuan membuat pekerjaan lebih } \\
\text { mudah bagi karyawan (knowledge } \\
\text { management system) }\end{array}$ & & & & \\
\hline
\end{tabular}

INOVASI (INNOVATION)

\begin{tabular}{|c|c|c|c|c|c|c|c|c|}
\hline \multirow{2}{*}{ VARIABEL } & \multicolumn{2}{|r|}{ INDIKATOR } & KO & \multicolumn{5}{|c|}{ PENILAIAN } \\
\hline & & & & 1 & 2 & 3 & 4 & 5 \\
\hline \multirow{6}{*}{ Innovation } & 1. & $\begin{array}{l}\text { Produk-produk yang kami luncurkan } \\
\text { (launching) adalah yang pertama dalam } \\
\text { kategorinya }\end{array}$ & I1 & & & & & \\
\hline & 2. & $\begin{array}{l}\text { Perusahaan/organisasi sering } \\
\text { memperkenalkan rentang/segmen baru } \\
\text { untuk produk/ layanan/program yang } \\
\text { sebelumnya tidak ditawarkan oleh } \\
\text { perusahaan ini }\end{array}$ & 12 & & & & & \\
\hline & 3. & $\begin{array}{l}\text { Perusahaan/organisasi sering menambah } \\
\text { produk/layanan/program baru untuk } \\
\text { rentang/segmen produk yang ada }\end{array}$ & 13 & & & & & \\
\hline & 4 & $\begin{array}{l}\text { Perusahaan/organisasi sering } \\
\text { memperbaiki/mengembangkan atau } \\
\text { merevisi produk/layanan/program yang } \\
\text { sudah ada }\end{array}$ & 14 & & & & & \\
\hline & 5 & $\begin{array}{l}\text { Perusahaan/organisasi sering merubah } \\
\text { produk /layanan/program dalam rangka } \\
\text { untuk mengurangi biaya }\end{array}$ & 15 & & & & & \\
\hline & 6 & $\begin{array}{l}\text { Perusahaan/organisasi sering mereposisi } \\
\text { produk/layanan/program yang sudah ada }\end{array}$ & 16 & & & & & \\
\hline
\end{tabular}

Terimakasih,

Cosmas Eko Suharyanto

1322202122 